\title{
Interactive graphics tool for the calculation and serviceability limit state stress check of bonded post- tensioned concrete beams according to brazilian codes via Autodesk Robot Structural Analysis Professional ${ }^{\circledR}$
}

\section{Ferramenta gráfico-interativa de cálculo e verificação de tensões no estado limite de serviço de vigas protendidas com pós-tração aderente para a norma brasileira através do Autodesk Robot Structural Analysis Professional ${ }^{\circledR}$}

P. K. K. NACHT a pedro.k.night@gmail.com

L. F. MARTHA a Ifm@puc-rio.br

\begin{abstract}
This work presents an interactive graphics computational tool for the verification of prestressed concrete beams with post-tensioned bonded tendons to the serviceability limit state (SLS) stress check according to the Brazilian code NBR 6118:2014. The tool is an add-in for Autodesk Robot Structural Analysis Professional ${ }^{\circledR}$, which serves as a structural modeling platform.

With data supplied by the user through a graphics user interface, the program here developed calculates all relevant prestress losses that occur throughout the structure's life-cycle, along with the prestress' equivalent loads during this period. The traditional calculation methods, obtained in the NBR 6118, are presented along with the modifications which had to be implemented in order to allow for incremental loss calculations. Usage examples and results are presented, validating the adopted methodology.

At the end of the software's calculation, the user receives two outputs: the prestress' equivalent loads in the Robot model and an Excel spreadsheet. The spreadsheet contains the resultant stresses in the beam and warns whether these are greater than the permissible stresses in the SLS stress check. The loads may then be used in other calculations, such as shear reinforcement.
\end{abstract}

Keywords: prestressed concrete beams, ABNT NBR 6118, serviceability limit state stress check, Autodesk Robot Structural Analysis Professional ${ }^{\circledR}$.

\section{Resumo}

Este trabalho apresenta o desenvolvimento de uma ferramenta computacional gráfico-interativa para a verificação de vigas de concreto protendido com pós-tração aderente ao estado limite de serviço (ELS), de acordo com a norma brasileira NBR 6118:2014. A ferramenta é um add-in para o Autodesk Robot Structural Analysis Professional ${ }^{\circledR}$, que serve como plataforma de modelagem estrutural.

A partir de dados fornecidos pelo usuário através de uma interface gráfica, o programa desenvolvido calcula todas as perdas de protensão que ocorrem ao longo da vida-útil da estrutura, assim como os carregamentos equivalentes à protensão durante este período. $\mathrm{O}$ trabalho apresenta os métodos de cálculo tradicionais, obtidos da NBR 6118, e as modicações que tiveram que ser feitas para permitir um cálculo incremental. Exemplos de utilização do programa também são apresentados, validando a metodologia adotada.

Ao fim do cálculo o usuário recebe duas saídas: os carregamentos equivalentes da protensão ao longo da vida-útil da estrutura no modelo do Robot e uma planilha Excel. A planilha contém os esforços e as tensões atuantes na viga ao longo de sua vida-útil e informa se estes valores ultrapassam os limites estabelecidos para o ELS. Os carregamentos podem ser utilizados para demais carregamentos, tal como no dimensionamento ao esforço cortante.

Palavras-chave: Vigas de concreto protendido, ABNT NBR 6118, Estado limite de serviço (ELS), Autodesk Robot Structural Analysis Professional ${ }^{\circledR}$.

Civil Engineering Department, Pontifícia Universidade Católica do Rio de Janeiro, Rio de Janeiro, Rio de Janeiro, Brasil. 


\section{Introduction}

The Building Information Modeling (BIM) philosophy is revolutionizing structural engineering. The fundamental concept is to bring all the information from the disparate disciplines into a single database. One then has a single structural model which incorporates all the structure's life-cycle information: architectural, structural, hydraulic, electric, mechanical, as-built, and maintenance projects. Prestressed concrete structures, however, tend to be modeled separately in specialized software which does not attempt to follow the BIM philosophy.

To aid in the unification of prestressed structural models with BIM, this work presents a computational tool for the serviceability limit state stress check of bonded post-tensioned concrete beams according to Brazilian codes via Autodesk Robot Structural Analysis Professional ${ }^{\circledR}$, henceforth referred to as Robot. This software, named Prestress, is an add-in for Robot, leveraging its structural modeling capabilities to obtain the loads and stresses arising from the prestress.

Robot was chosen as the platform for Prestress because it is part of the Autodesk environment. BIM does not require that a single company's package be adopted, but open-source databases, commonly represented by IFC files, cannot as of yet contain all of the "intelligence" of a model [1]. For this reason, though it is not strictly necessary, adopting a company's closed environment simplifies the implementation of the BIM philosophy for now. With Robot as a platform, Prestress can now unify the prestressing calculations to those of the global structure. Though not yet implemented, Prestress can still be extended to add the prestressing to an Autodesk Revit 4D model to check for possible interferences and inclusion in the structure's life-cycle analysis.

From a structural model created within Robot and prestressing data given by the user, prestress losses are calculated, isostatic bending moments are obtained and equivalent loads are applied. The program's calculations are boundary-condition-agnostic, successfully dealing with isostatic and statically indeterminate beams. The effects of the boundary conditions are considered by Robot and incorporated in Prestress. Once the (possibly statically indeterminate) stresses are obtained, the software then performs a serviceability limit state stress check on the beam and generates an .xlsx file containing the results.

A limitation of Prestress at present is that it cannot correctly calculate structures which are built in stages. While Robot has what it calls "phase structures", its API does not implement any method by which external programs (such as Prestress) can retrieve information regarding the different construction phases [2]. It is therefore impossible for Prestress to accurately calculate segmental bridges or prefabricated beams with cast-in-place decks which are usually considered to work with the beam for live-loads.

There are at present already multitudes of software in the market which aid the engineer in the design of prestressed concrete structures. midas Civil ${ }^{\circledR}$, SAP $2000^{\circledR}$, ADAPT-ABI ${ }^{\circledR}$, ADAPT-PTI $\mathbf{R C}^{\circledR}$, RAPT $^{\circledR}$ and Nemetschek Scia ${ }^{\circledR}$ are but a few of the available options. All of these are evidently far more advanced and robust

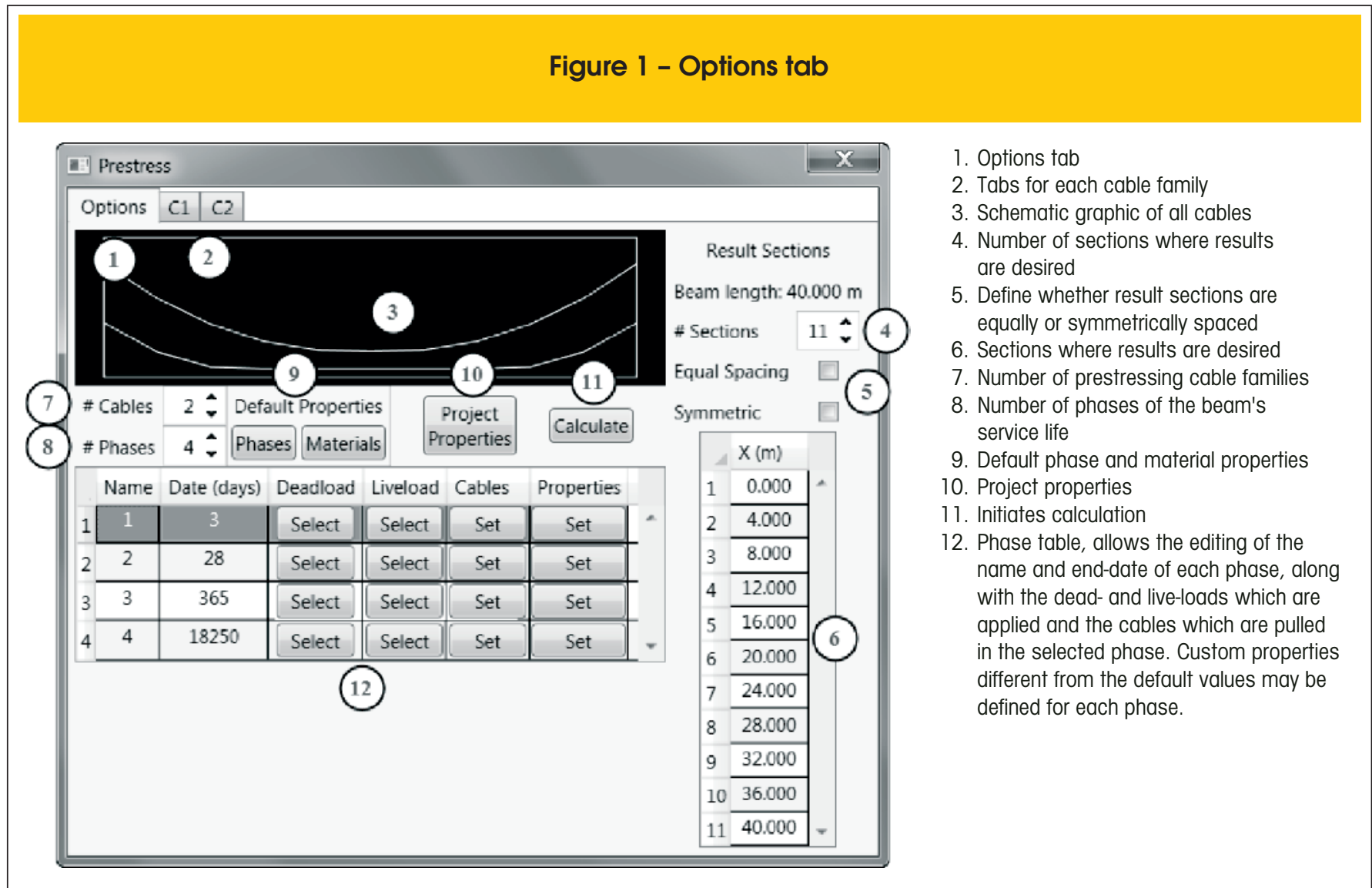




\section{Figure 2 - Cable tab}

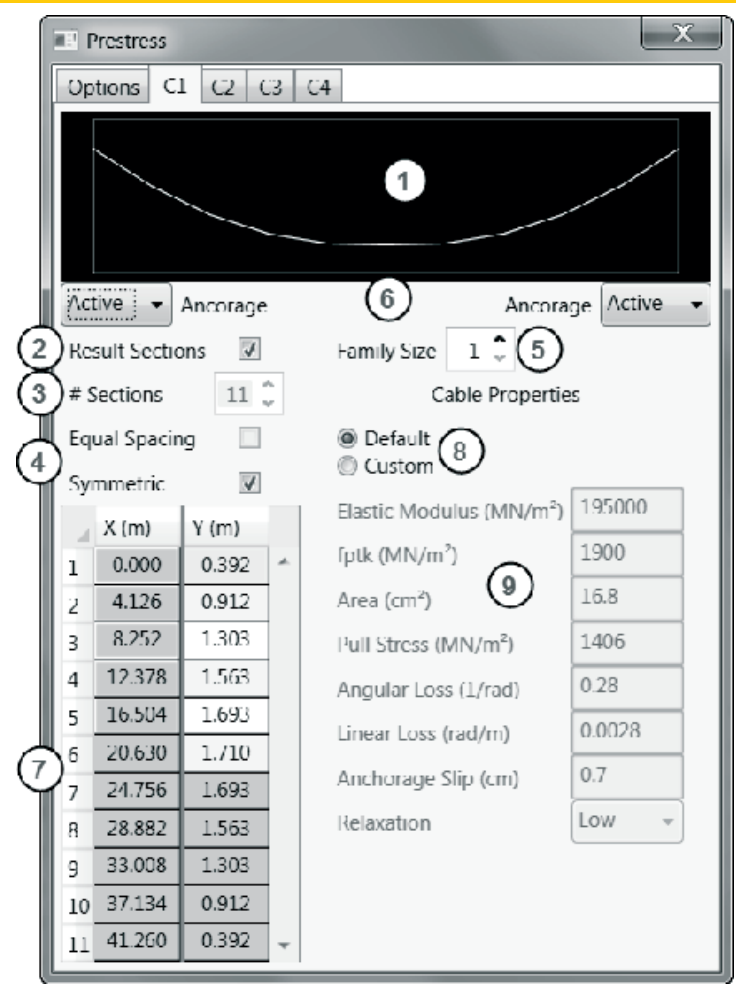

1. Schematic graphic of the cable

2. Defines whether the cable sections are equal to the result sections

3. Number of sections

4. Define whether the cable sections are equally and/or symmetrically spaced

5. The number of cables which have the same profile and properties

6. Define whether the anchorages in the start and end of the cable are active or passive

7. Cable profile

8. Defines whether the cable properties are default (as defined in the Options tab) or custom

9. Cable properties

than the software here developed. However, of the above only ADAPT-PT/RC ${ }^{\circledR}$ currently performs the calculations and serviceability checks according to the Brazilian codes, but it is a 2D-only platform. There are other programs, such as those developed by Bortone [3] and Lazzari et al. [4], which fall into the same category. Prestress is unique in that it follows the Brazilian codes and allows the user to work in a 3D space. Compared to the works of Bortone and Lazzari et al., it also has the advantage of not being a stand-alone program. This means the engineer need not create two structural models: one to calculate the prestressed element and another to obtain the behavior of the rest of the structure. Having the prestressing loads within the global structural model also allows the user to observe the effect of the prestress in the entire structure. The following sections will present the procedures adopted by the software and two examples. One example is that of an isostatic beam, while the other is of a statically indeterminate structure. Each example presents the information relevant for prestressing and the file containing the results.

\section{Procedure}

\subsection{Input}

The Prestress software requires that the user already have a complete structural model defined in Robot, including constraints and load cases. It is essential that the beam be allowed to deform according to the real boundary conditions, therefore great care must be taken in the definition of the constraints. For instance, if a beam's two extremities have constraints which do not allow the beam to be compressed, a large part of the prestress will be lost. The user then selects the beam to be prestressed, which may be composed of one or more bar segments. Via a graphical user interface, the engineer may input the requisite prestressing data. This includes the number of cables, each cable's longitudinal layout, section area, pull stress, and relevant prestress loss coefficients, as well as material properties for both concrete and steel and the desired level of prestress: limited or complete prestress. Partial prestress, which permits the concrete to crack in tension, is not allowed. The units adopted by Prestress are taken directly from the Robot model, so as to allow the user to work with the unit system (s)he has previously defined.

Another key piece of data the user must present is the different phases of a structure's lifecycle. The suggested minimum number of such phases is four [5], representing: the age of concrete at prestressing; when loads other than self-weight and prestress are applied; one year; and the end of the structure's service life. The user, however, is free to alter both the number and dates of phases. Each phase is defined by the concretes age at the end of the phase, the dead and live loads that are applied and the cables that are jacked on that phase, along with representative values of temperature and humidity for that phase. Should the prestressing operation occur in multiple stages, this should be represented in the user's input, preferably by including additional phases. Figures [1] and [2] show the windows where the user enters all relevant data. 
Interactive graphics tool for the calculation and serviceability limit state stress check of bonded post-tensioned concrete beams according to brazilian codes via Autodesk Robot Structural Analysis Professional ${ }^{\circledR}$

Figure 3 - Variable-height beam with straight cable

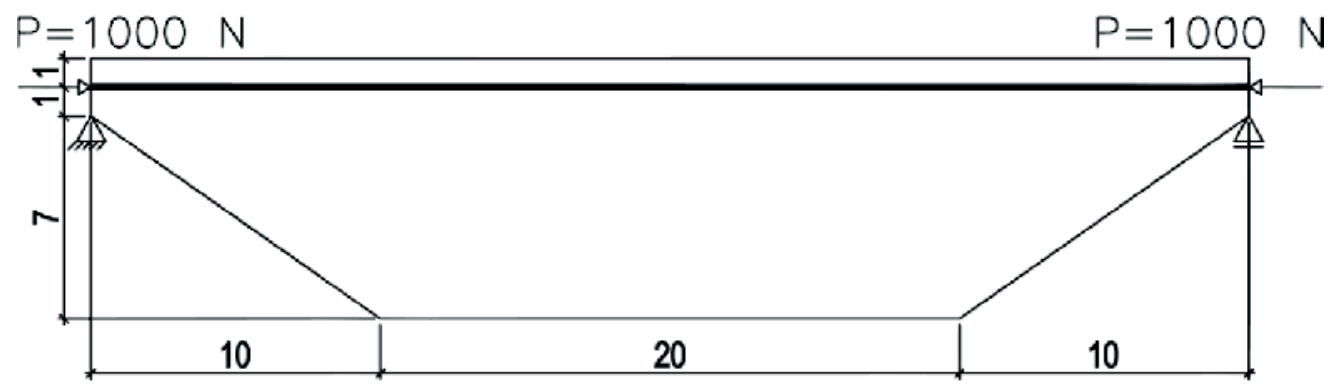

A Elevation

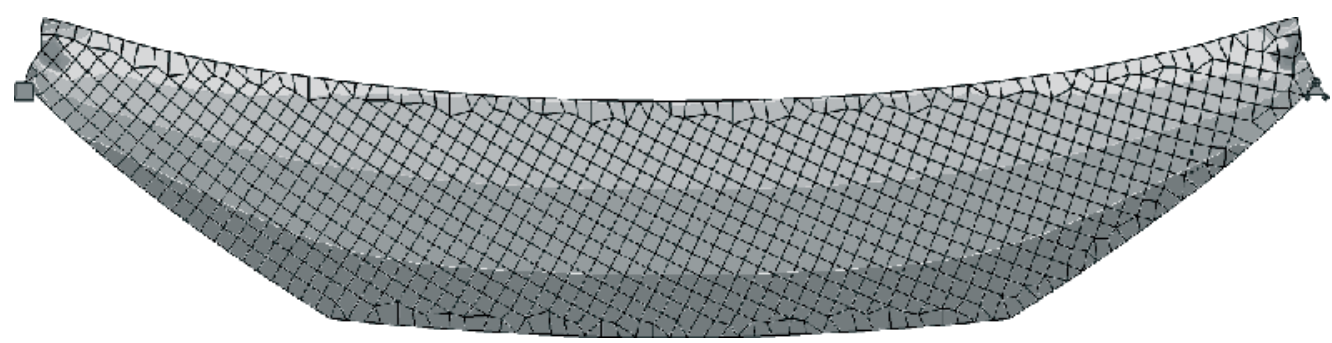

B Resultant stresses and deformation

Figure 4 - Variable-height beam with variable cable

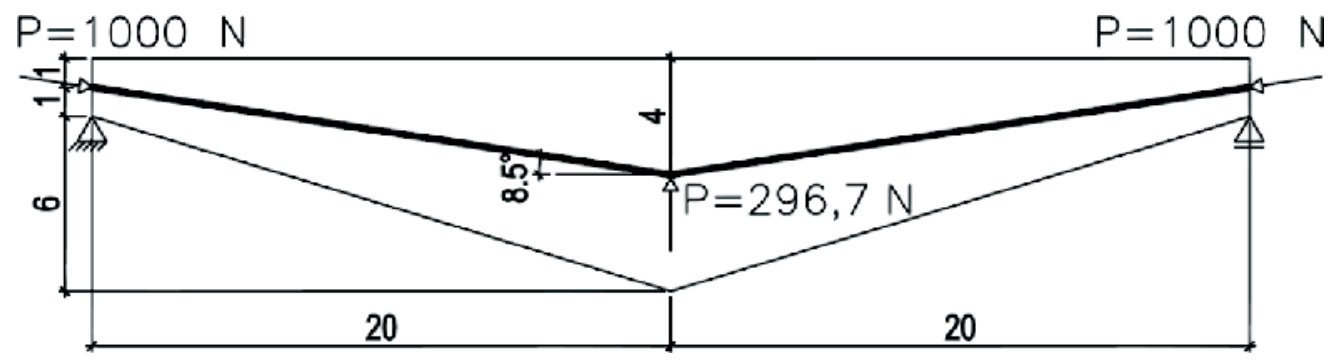

A Elevation

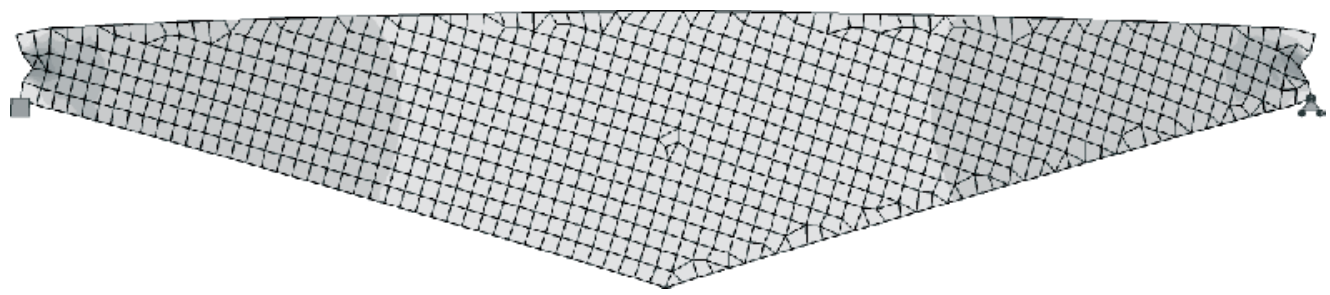

B Resultant stresses and deformation 
With this data Prestress then calculates all relevant prestressing losses: friction, anchorage slippage, concrete elastic deformation, creep and shrinkage, and steel relaxation.

\subsection{Equivalent loads}

A curved cable under tension tends to straighten, but this is impeded by the concrete and its self-weight, so the cable applies a distributed force along the beam's span. The standard method of defining an equivalent load to simulate this force was presented by Lin [6]. For a beam with a parabolic cable of length $L$, pull-force $P$ and maximum deflection $e$, the equivalent distributed load is given by Equation [1].

$$
q=\frac{8 P \cdot e}{L^{2}}
$$

This method, however, is not generic since it requires a beam of constant section [7]. Figures [3], [4] and [5] present three different variable beams. The first presents a beam of variable height, prestressed with a straight tendon. Though the tendon has no deflection, the eccentricity of the cable to the beam's centroid is variable, leading to a flexural stress-state in the beam. The second presents a beam with variable height but with a polygonal cable which always follows the beam's centroid. Though the cable has a deflection, in this case the beam's stress-state is that of pure compression. The third case presents a beam with a sudden change of section. It is clear that where the cable is aligned with the centroid, the beam is under pure compression, but where the cable is offset from the centroid, the beam presents a bending moment. It is there- fore necessary to adopt a more generic function for equivalent loads. The adopted solution applies concentrated loads according to Equation [2] at every section $i$ where the cable's layout was defined, where $M_{i}$ and $M_{i+1}$ are the isostatic prestressing bending moments at the current section and the following one, respectively, and $\Delta M$ is the difference between the bending moment immediately to the right and left of the current section and is therefore only non-zero if there is a crosssection discontinuity at point $i$. If such a discontinuity occurs, a concentrated moment equal to $\Delta M$ must also be applied.

$$
Q_{i}=\frac{M_{i+1}-M_{i}-\Delta M_{i}}{L}-\sum_{j=1}^{i-1} Q_{j}
$$

This method generates a polygonal approximation of the beam's prestressing bending moment diagram, regardless of the boundary conditions. If the structure is statically indeterminate, then the boundary conditions will naturally generate the correct diagram. This equivalent load method also satisfies the condition of being self-balanced, generating no reactions on supports in isostatic structures. Prestress losses are also trivially considered, since the values of $M_{i}$ and $M_{i+1}$ are naturally calculated after all relevant losses. Figure [6] shows an example of a beam without cross-section discontinuities (therefore $\Delta M$ is always null) under a constant distributed load and the linear approximation via Equation [2]. The errors here are of approximately $\pm 1 \%$, but this is evidently affected by the number of points where concentrated loads are defined.

The equivalent loads of each phase of the structure's service life are left in the model after Prestress is complete, allowing the user to make use of these loads if so desired.

\section{Figure 5 - Beam with section discontinuity and a straight cable}

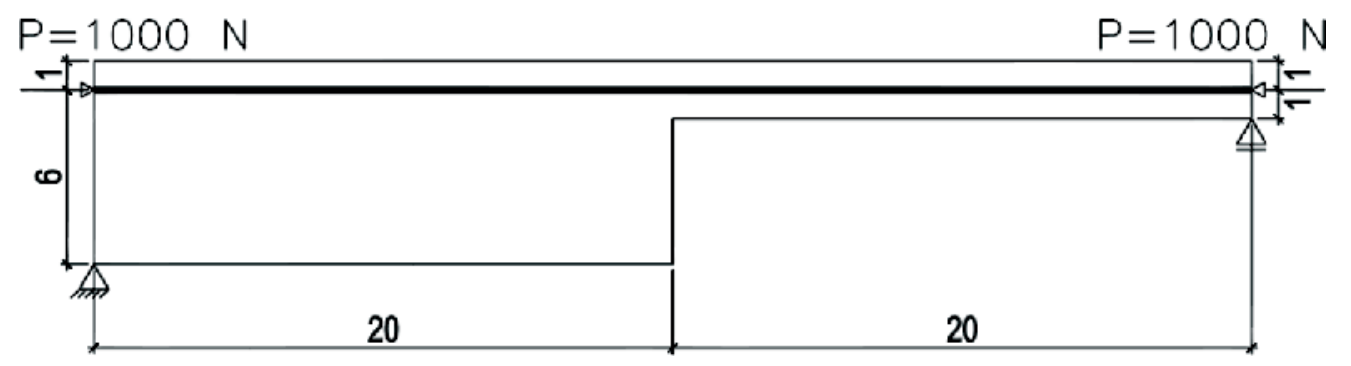

A Elevation

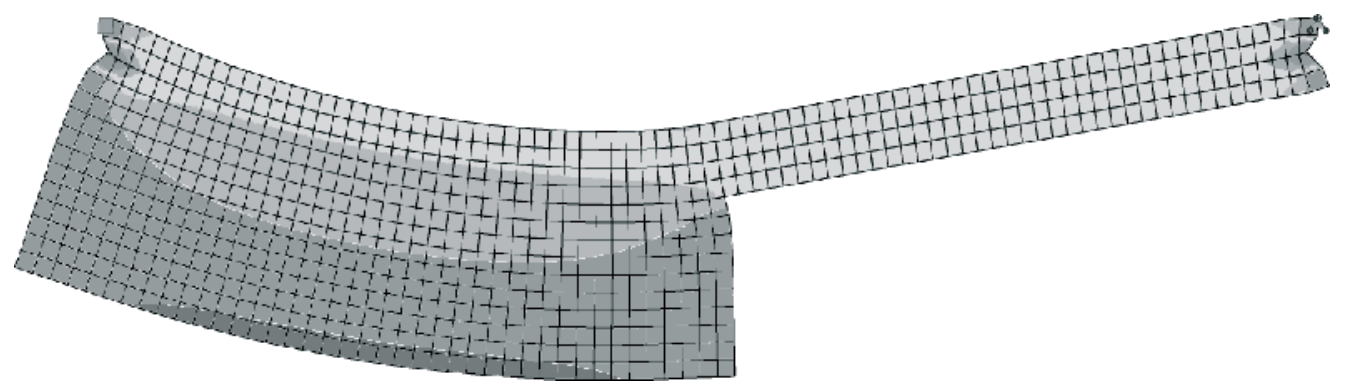

B Resultant stresses and deformation 


\subsection{Prestress losses}

A prestressed cable is jacked up to a specified stress. This stress, however, is not constant along the cable's length, nor is it constant in time. The losses can be simply bundled into two groups: immediate and progressive losses. The immediate losses, as the name would imply, happen at the act of jacking. These are losses due to: friction between the cable and its duct; anchorage slippage; and the elastic deformation of the concrete. The progressive losses are time-dependent, ever-approaching an asymptotic value at the end of the beam's service-life. These are the losses due to steel relaxation and concrete creep and shrinkage. The methods adopted by Prestress are summarized below.

Friction losses are calculated according to item 9.6.3.3.2.2 of the NBR 6118:2014 [8], which is itself simply the traditional equation for such losses, seen in Equation [3], where $P_{0}$ is the pull force; $\mu$, the angular friction coefficient; $\boldsymbol{\alpha}(x)$, the total absolute angular variation from the anchorage until point $x$; and $k$, the linear friction coefficient.

$$
P(x)=P_{0} \cdot e^{-\mu \alpha(x)-k \cdot x}
$$

Anchorage slippage losses are calculated by solving Equation [4], where $A_{p}$ is the cable's cross-section's area; $E_{p}$, the cable's modulus of elasticity; $\delta$, the anchorage's slip length; $\Delta P(x)$, the loss of prestress due to anchorage slippage until point $x$; and $X$ is the point where these losses end. Prestress adopts the cable's stress diagram after friction losses and finds $X$ by incrementally calculating the area between this diagram and its version mirrored over $P(X)$.

Figure 6 - Beam under distributed and equivalent loads

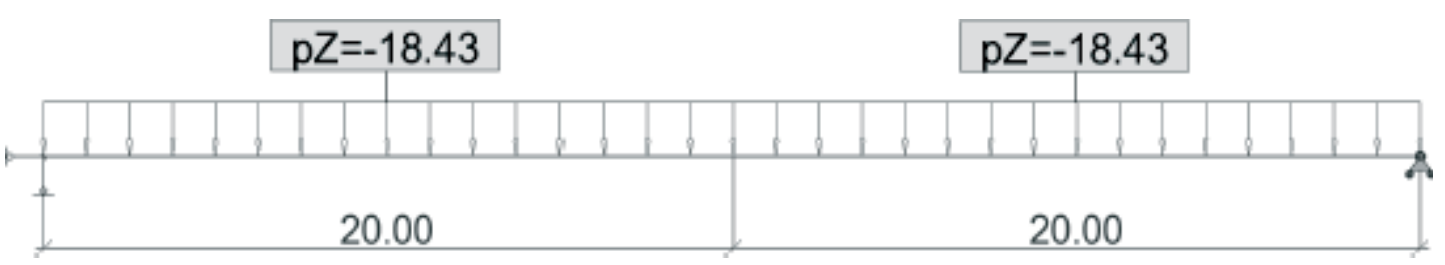

A Beam under constant distributed load

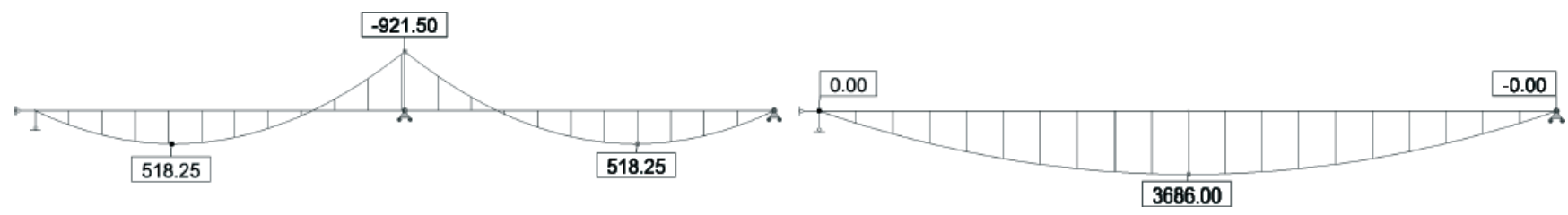

B Statically indeterminate and isostatic bending moment diagrams under distributed load

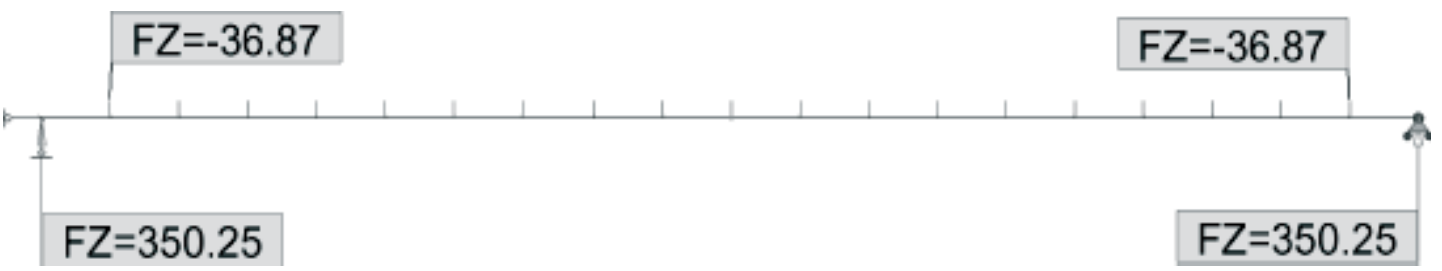

Approximation of distributed load

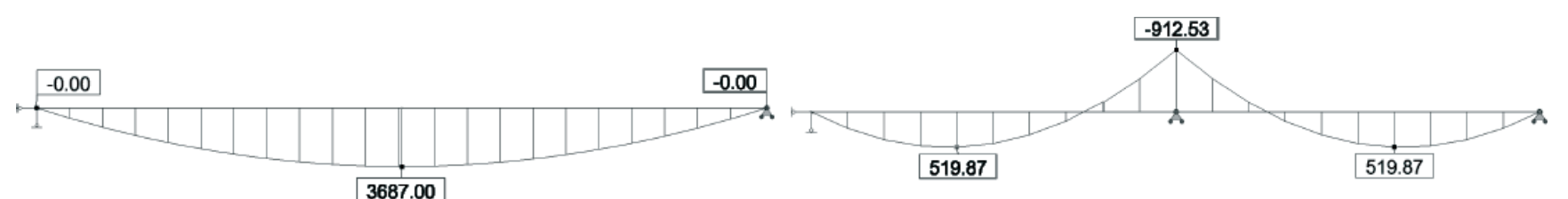

D Approximate isostatic and statically indeterminate bending moment diagrams 


$$
A_{p} \cdot E_{p} \cdot \delta=\int_{0}^{X} \Delta P(x) \mathrm{d} x
$$

Losses due to the elastic deformation of concrete from prestressing and dead loads are also considered. The stresses due to dead loads and equivalent prestressing loads are calculated by Robot and Equation [5] is applied, where $\Delta \sigma_{p}$ is the change of stress in the steel; $\Delta \sigma_{c}$, in the concrete; and $\alpha_{p}$ is equal to the ratio of the steel and concrete moduli of elasticity.

$$
\Delta \sigma_{p}=\Delta \sigma_{c} \cdot \alpha_{p}
$$

Prestress currently only calculates post-tensioned bonded cables. Such cables only suffer elastic deformation losses due to the prestressing of subsequent cables, but not due to their own jacking. If cables are pulled at different dates, then the effect of the jacking of the latter cables will only be computed at that later date. This allows the software to consider the effect of the differed losses (discussed below) on the former cables prior to the influence of the elastic deformation losses.

The treatment of the progressive losses is more complex. These losses are interdependent, with the result of one altering the result of the other and visa-versa. The methods adopted by Prestress are those present in Annex A of the NBR 6118 [8]. However, they do not allow for the consideration of this interdependence and therefore had to be slightly modified. Below are described the methods used by the software. When calculating each differed loss for a phase $i$ the program assumes the stresses in phase $i-1$ are constant. With a sufficient number of phases (at least four, as described in Section [2.1]), this allows for an approximation of the true results [5].
Creep losses are calculated by the traditional method of considering a factor $\varphi$ which represents the deformation increment over time, as seen in Equation [6]:

$$
\Delta \sigma_{p}=\varphi \cdot \sigma_{c} \frac{E_{p}}{E_{c}}
$$

Item A.2.2.3 of the NBR 6118 [8] considers $\varphi$ as the sum of three parts: $\varphi_{a}$, which represents the quick, plastic deformation which occurs in the first 24 hours; $\varphi_{f}$, the slow, plastic deformation; and $\varphi_{d}$, the slow, elastic deformation.

$\varphi_{a}$ is calculated by Prestress precisely as in the Brazilian code according to Equation [7], where $\beta_{1}$ is the fraction of the concretes 28 -day strength present on $t_{0}$, the moment the load is applied. The code actually defines the boundaries differently, with the first case being used for concretes with a compressive strength between 20 and $45 \mathrm{MPa}$, and the second for concretes between 50 and $90 \mathrm{MPa}$. Those used here are equivalent, but also allow for concretes with strengths between 45 and $50 \mathrm{MPa}$. Conservatively, such concretes would fall under the second case. Since this portion of the concretes creep occurs in the first 24 hours, it is only considered in the first phase after a load is applied.

$$
\varphi_{a}\left(t_{0}\right)= \begin{cases}0,8\left(1-\beta_{1}\left(t_{0}\right)\right) & \text { for } f_{c k} \in[20,45] \mathrm{MPa} \\ 1,4\left(1-\beta_{1}\left(t_{0}\right)\right) & \text { for } f_{c k} \in(45,90] \mathrm{MPa}\end{cases}
$$

$\varphi_{f}$ is calculated in a form almost identical as that given in the code, as shown in Equation [8], where $\varphi_{f \circ}$ is the asymptote of $\varphi_{f}$ and $\beta_{f}$ is a time function for such losses. The only difference between this function and the one in the NBR 6118 [8] is that instead of being restricted to $t_{0}$, the moment the load is applied, it allows the creep increment to be found between any two moments in time. This

\section{Figure 7 - Incremental prestressing loss due to slow, plastic concrete creep. With the increase in humidity over time the final loss is reduced. To disconsider the humidity's variation over time, however, may lead to inaccurate results}

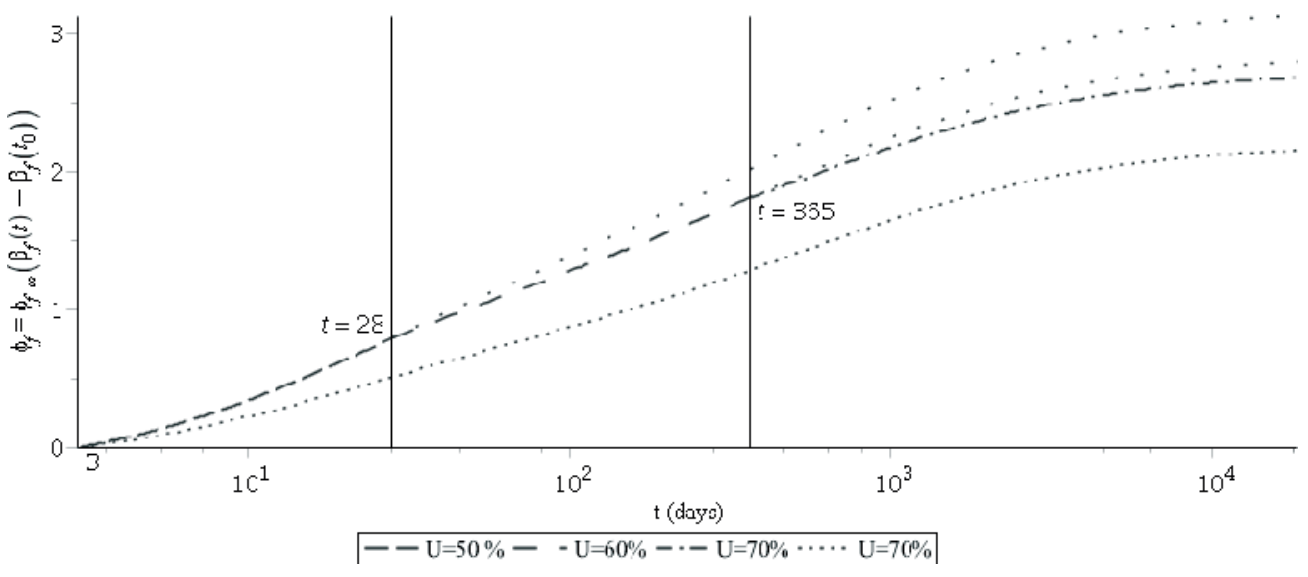


Figure 8 - Incremental prestressing loss due to concrete shrinkage. With the increase in humidity over time the final loss is reduced. To disconsider the humidity's variation over time, however, may lead to inaccurate results

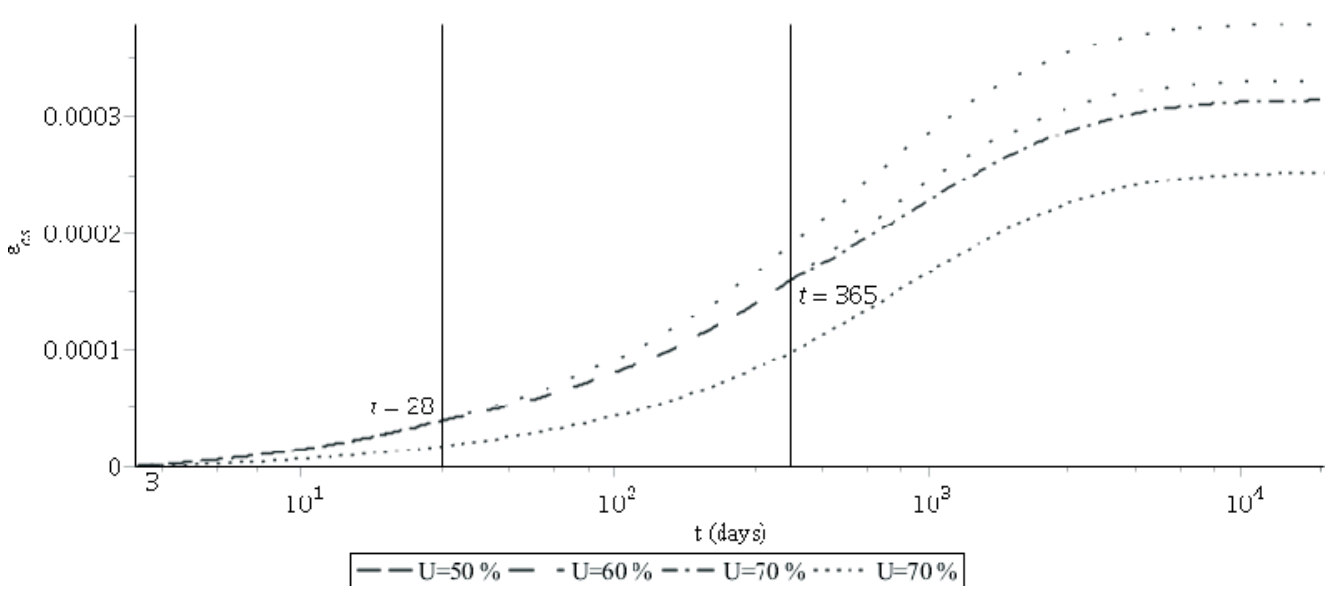

allows the creep from a load applied at $t_{0}$ to be computed from $t_{0}$ to $t_{1}$ and from $t_{1}$ to $t_{2} \ldots$ all the way to $t_{n}$, which defines the end of the structure's life-cycle. Both $\varphi_{f o}$ and $\beta_{f}$ are functions of the humidity in the air, which means that calculating different phases with varying humidity leads to a different result than if an average value were considered. Figure [7], for instance, demonstrates a fictitious example of a beam in an environment with ever-increasing humidity. Notice how the final result considering only the humidity of the last phase (which represents 49 of the beam's 50 -year service life) leads to a result which is $25 \%$ lower than if the varying humidity in the first year is considered.

$$
\varphi_{f}=\varphi_{f \infty}\left(\beta_{f}\left(t_{i}\right)-\beta_{f}\left(t_{i-1}\right)\right)
$$

$\varphi_{d}$ is the portion which is most modified. For the first increment of time its value is obtained via Equation [9], precisely as defined in the Brazilian code [8]. For every other increment of time, however, Equation [10] must be used. This occurs due to the peculiar behavior of the code's method, which implies in a non-zero $\varphi_{d}$ for $t_{1} \approx t_{0}$.

$$
\varphi_{d}=0,4 \frac{t_{1}-t_{0}+20}{t_{1}-t_{0}+70}
$$

$$
\varphi_{d}=0,4\left(\frac{t_{i}-t_{0}+20}{t_{i}-t_{0}+70}-\frac{t_{i-1}-t_{0}+20}{t_{i-1}-t_{0}+70}\right)
$$

The implementation of prestressing losses due to concrete shrinkage does not require any modifications to the method present in the NBR 6118 [8], seen in Equation [11], where $\varepsilon_{c 5^{\circ}}$ is the maximum value and $\beta_{s}$ is a time function. Given the deformation increment

\section{Figure 9 - Incremental prestressing loss due to steel relaxation. With the reduction of steel stress over time due to other differed losses, the final loss is reduced}

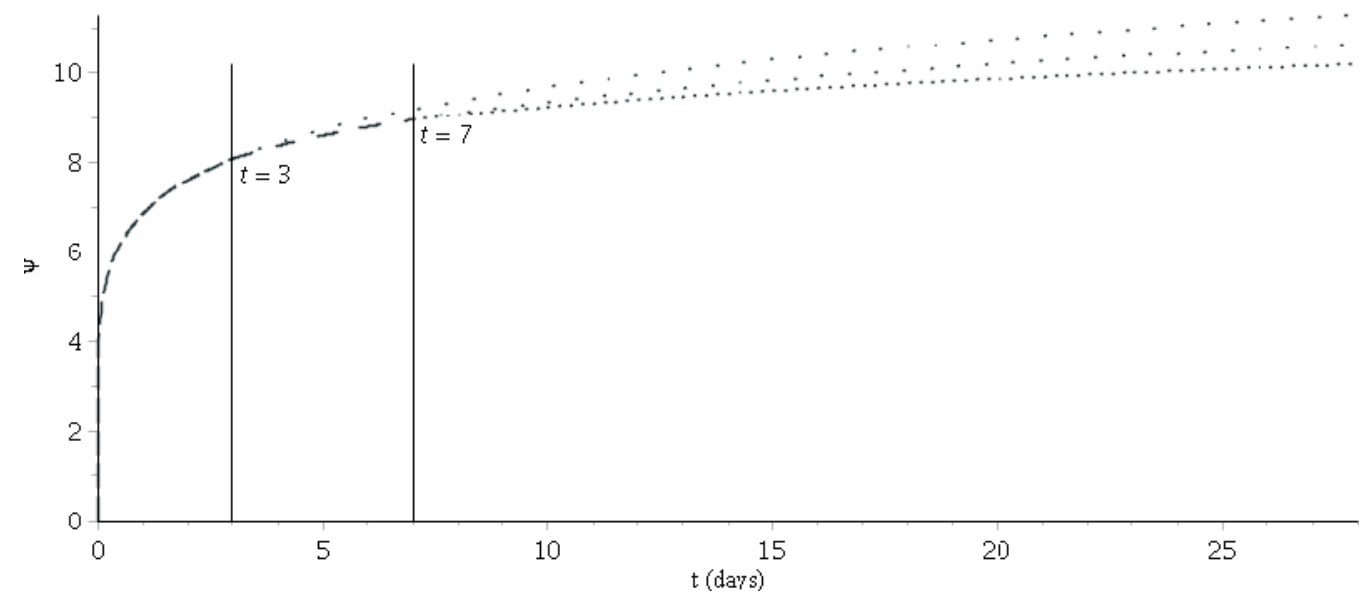


between two moments, Prestress then needs only to multiply this value by the steel's modulus of elasticity to obtain the relevant loss of stress. Figure [8] shows the shrinkage losses over time for a structure in an increasingly humid environment.

$$
\epsilon_{c s}\left(t_{i}, t_{i-1}\right)=\epsilon_{c s \infty}\left[\beta_{s}\left(t_{i}\right)-\beta_{s}\left(t_{i-1}\right)\right]
$$

There is, however, one note that must be made in regards to shrinkage losses and that is that the actual value of shrinkage deformation is a function of a beam's boundary conditions. The beam segment of a plane frame, for instance, will suffer less shrinkage deformation than a simply supported beam due to the stiffness of the pillars. Such effects are not considered by the software, which assumes for these losses that the beam has no restrictions to axial deformations. This is a conservative assumption which leads to greater prestressing losses.

Steel relaxation losses are calculated based on item 9.6.3.4.5 of the NBR 6118 [8]. The method, however, had to be modified somewhat to allow for an incremental method as shown in Equation [11], where $\psi_{i}$ is the relaxation that occurs between $t_{i}$ and $t_{i-1} ; \psi_{1000, i-1}$, the relaxation coefficient for 1000 hours, obtained in the code's Table 8.4 , considering the cable stress at moment $t_{i-1}$; and $t_{0}$, the moment the cable was pulled. Since $\psi_{1000}$ is a function of steel stress, which is altered by the other progressive losses, the value of $\psi_{1000}$ is in fact variable in time. Figure [9] shows a fictitious example of a cable where the value of $\psi_{1000}$ is progressively reduced, simulating the effect of the other differed losses.

\section{Figure 10 - Plan and cross-section of Santa Isabel Viaduct. Reprinted from Cerne Engenharia (11)}

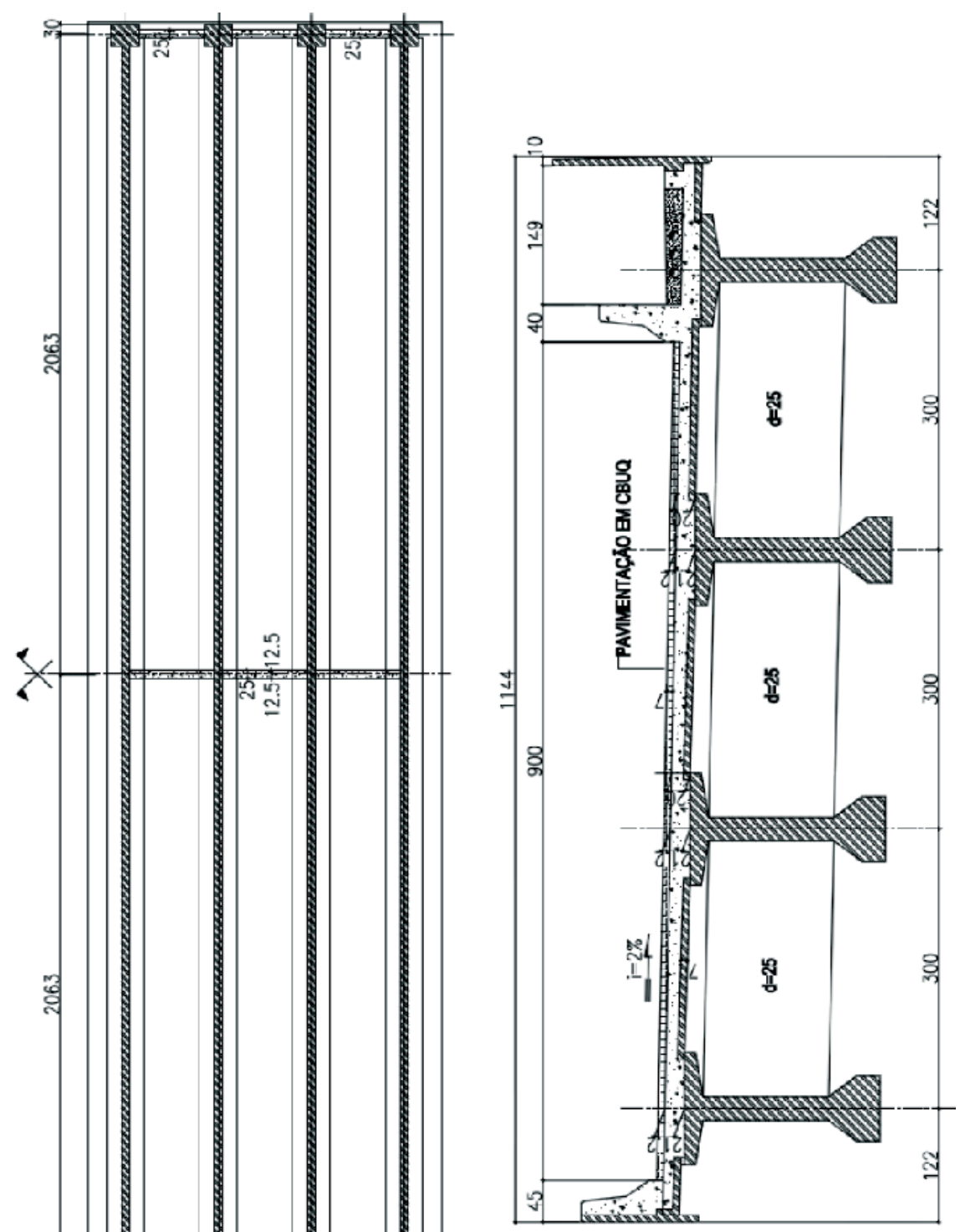




$$
\psi_{i}=\psi_{1000, i-1}\left(\left(\frac{24\left(t_{i}-t_{0}\right)}{1000}\right)^{0,15}-\left(\frac{24\left(t_{i-1}-t_{0}\right)}{1000}\right)^{0,15}\right)
$$

After calculating each of these losses for every phase of a beam's service life, Prestress can then apply equivalent loads which simulate the prestress. With these equivalent loads in combination with the live and dead loads along the structure's service life, the software can then perform the serviceability limit state stress check.

\subsection{Serviceability limit state stress check}

A prestressed structure must be checked against two limit states: ultimate and serviceability. The ultimate limit state (ULS) certifies that the structure will not collapse when under load. The serviceability limit state (SLS) checks that, if ULS is also satisfied, the structure will be adequate for use. A beam which withstands a load but does so with excessive cracking or deflection will not give its users peace of mind and may forbid the use of sensitive machinery. Both limit states are equally important, but only SLS, which is usually the critical verification [9], is checked by Prestress. The user must therefore perform ULS checks by some other means. The Brazilian code defines three levels of live loads, each of which is given a coefficient: rare $\left(\psi_{0}\right)$, frequent $\left(\psi_{1}\right)$, and almost-permanent $\left(\psi_{2}\right)$. For a nominal live load $Q$, the frequent load is therefore equal to $\psi_{1} Q$, for example. The values of the coefficients can be found in Table 11.2 of NBR 6118 [8] or Table 6 of NBR 8681 [10]. Table 13.4 of NBR 6118 [8] states that depending on the environmental conditions (CAA, as defined in Table 6.1 of the code), different stresses are permissible:

- If the environmental conditions are defined as CAA I or II, concrete cracking is permitted with a specified maximum nominal crack width $\left(w_{k, \max }=0,2 \mathrm{~mm}\right)$ considering frequent loading. This is defined as partial prestress;

- For CAA III or IV, stresses must be checked in two conditions: there must be no tensile stresses in the concrete under almostpermanent loads (ELS-D) and tensile stresses below the concretes tensile strength in flexure $\left(f_{c t f}\right.$, as defined in item 8.2.5 of NBR 6118) are permissible under frequent loads (ELS-F). This is defined as limited prestress;

- Though never obligatory for post-tensioned structures, there is also a stricter check which only allows tensile stresses below the concretes tensile strength under rare loads (ELS-F) and forbids tensile stresses under frequent loads (ELS-D). This is defined as complete prestress.

Another SLS check is for excessive compression in the concrete (ELSCE) as per item 17.2.4.3.2.a) of the NBR 6118 [8]. Here the compression must not be greater than $70 \%$ of the concretes strength $f_{c k j}$ on the date in question, considering a factor of 1.1 on the prestressing loads. Prestress performs SLS checks under either limited or complete prestress.

Item 9.6.1.3 of the NBR 6118 [8] states that the nominal prestress can be considered equal to the value obtained after all required

\section{Figure 11 - Prestressing data and cable profiles of Santa Isabel Viaduct. Reprinted from Cerne Engenharia (11)}
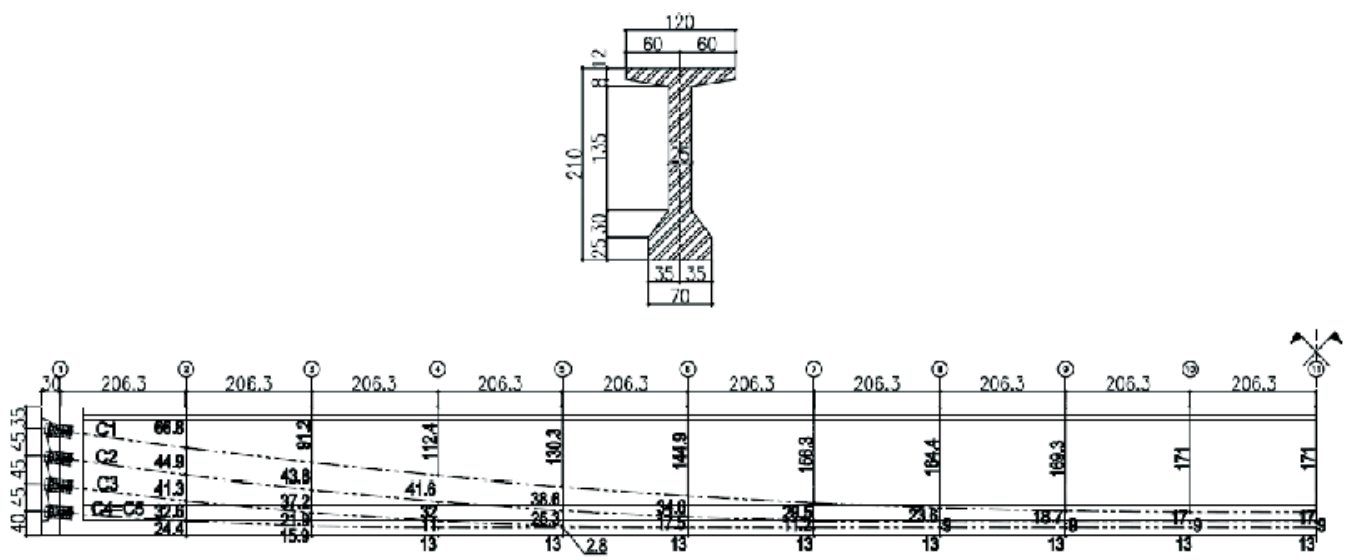

- TABELA DE PROTEN\&AO-

\begin{tabular}{|c|c|c|c|}
\hline CABO & $Q$ & $\begin{array}{c}\text { FORCCA. DO } \\
\text { CABD } \\
(\mathrm{kN})\end{array}$ & $\begin{array}{c}\text { A ONGAMFN'O } \\
\text { TO N KORICO } \\
(\mathrm{cm}) \\
\end{array}$ \\
\hline $\mathrm{C} 2$ & 1 & 2362 & 28.2 \\
\hline $\mathrm{C} 3$ & 1 & 2362 & 28.1 \\
\hline C1 & 1 & 2362 & 28.3 \\
\hline${ }^{*} \mathrm{C}<\mathrm{C} 5$ & 2 & 2362 & 28.5 \\
\hline
\end{tabular}

* VLR NOTA 4
NOTAS:

1 - Concreto estrutural fck $2 \angle$ DMPa.

2 - Os casos devem ser protendicos na ordem ca Tcbelc de Protensc̃o e o a o gagcmento teórico dado é caculaco cntes cc crcvç̧⿸丆口 do cone.

protensåo $\mathrm{CO}_{03}$ cajos deve seguir o segu'nte crorsgrama:

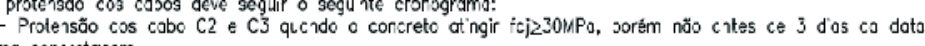
ca última conc'etagem.

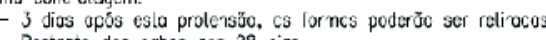

- Restante dos cabos aos 28 cas

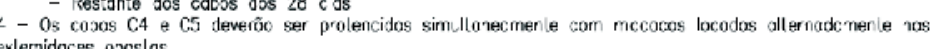

exlernidaces oxoslas.
9 - vc o'es acotodos pcro o cálcL o do alongamento téricc:

$$
\begin{aligned}
& { }_{\mathrm{C}}-195000 \mathrm{MPo} \\
& \widehat{A}_{\mathrm{p}}-16.30 \mathrm{~cm}
\end{aligned}
$$


losses as calculated in Section [2.3], unless the losses are greater than $35 \%$ of the initial jacking force. In such a case, the nominal prestress must be considered as $\pm 5 \%$ the calculated value. Regardless of the magnitude of the losses, Prestress always considers this variation of the nominal prestress force.

The stress and SLS-check results for the top and bottom fibers of each section are saved in an .xlsx file, examples of which can be seen in Section [3].

\section{Examples}

\subsection{Santa Isabel Viaduct}

The Santa Isabel Viaduct [11] is an isostatic structure which pres- ents a single $41,26 \mathrm{~m}$ span. The cross-section is composed of four prefabricated beams supporting a $20 \mathrm{~cm}$-thick cast-in-place deck. The beams are placed on neoprene bearing pads which allow them to deform in all directions. Figures [10] and [11] and Table [1] present all the relevant information for the prestressing of the beams.

The Robot model adopted is shown in Figure [12]. As stated in Section [2.1], it is important to observe the boundary conditions. Since the beams are supported by neoprene pads which allow for both rotation and displacement of the beams, the model was created with all but one of the supports resisting only vertical displacements. A single support is given additional constraints in order to create a stable model. Also note the difference in cross-section properties between the model and the information given in Table [1] due to the simplification of the section. Since Prestress will adopt the section given in the model,

\section{Figure 12 - Robot model for the Santa Isabel Viaduct}

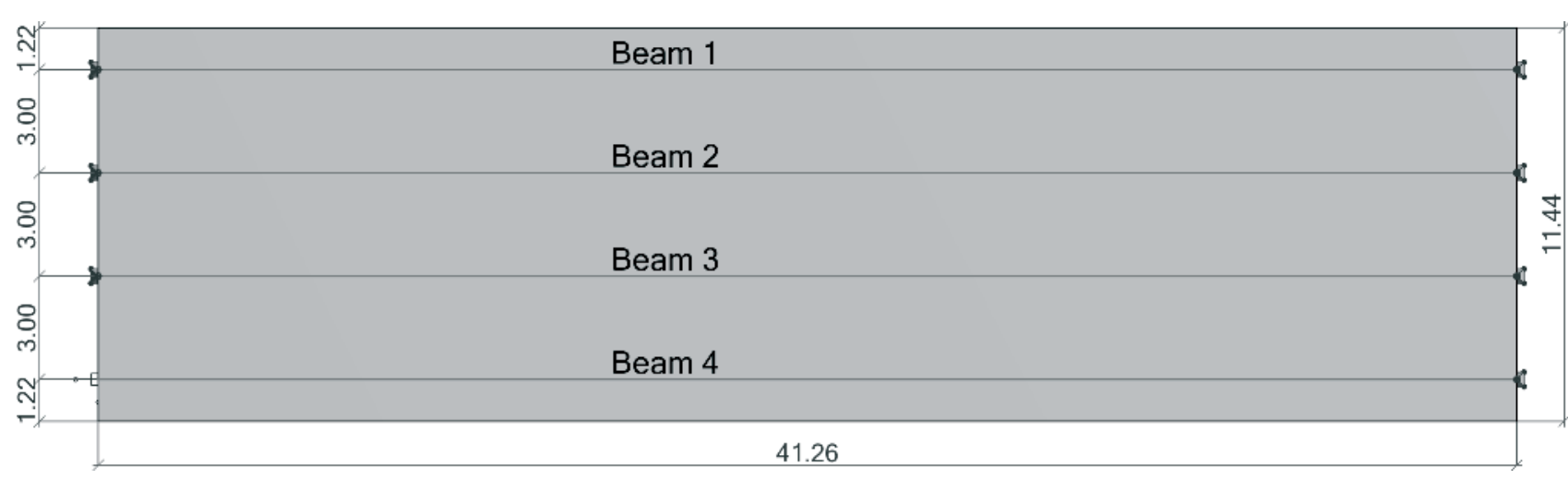

A Plan

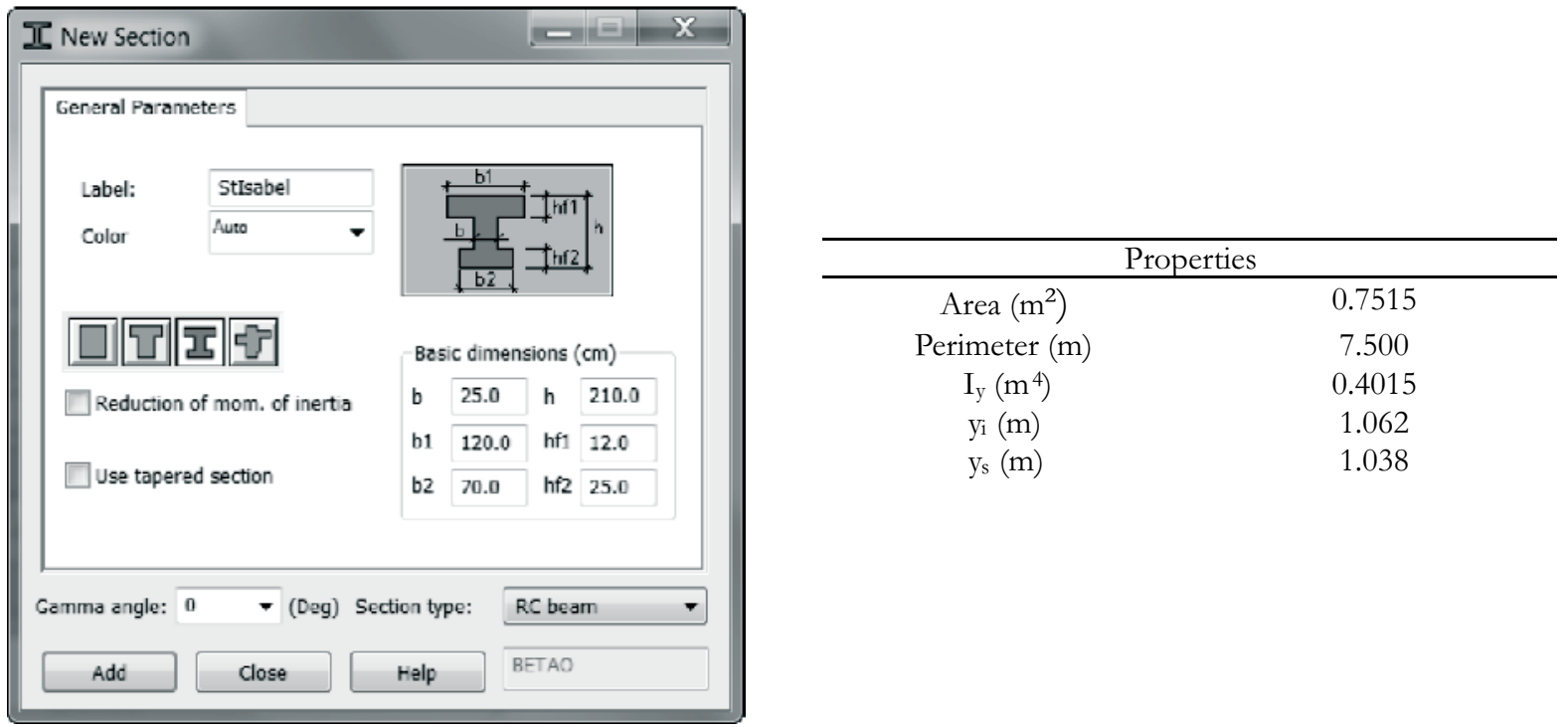

B Beam cross section 


\section{Table 1 - Properties of Santa Isabel Viaduct}

\begin{tabular}{|c|c|c|c|}
\hline \multicolumn{2}{|c|}{ Properties } & \multicolumn{2}{|c|}{ Limited prestress } \\
\hline Area $\left(m^{2}\right)$ & 0.8570 & Steel & CP-190 RB \\
\hline Perimeter (m) & 7.053 & $f_{p+k}\left(k N / c^{2}\right)$ & 190 \\
\hline$I_{y}\left(m^{4}\right)$ & 0.4661 & $f_{p y k}\left(k N / c^{2}\right)$ & 170 \\
\hline$y_{i}(m)$ & 1.045 & $\sigma_{\mathrm{pi}}\left(\mathrm{kN} / \mathrm{cm}^{2}\right)$ & 140.6 \\
\hline$y_{s}(m)$ & 1.055 & $\mathrm{E}_{\mathrm{p}}\left(\mathrm{kN} / \mathrm{mm}^{2}\right)$ & 195 \\
\hline Concrete type & CPV-ARI & $A_{p}\left(m m^{2}\right)$ & 1680.0 \\
\hline $\mathrm{f}_{\mathrm{ck}}(\mathrm{MPa})$ & 40 & $\mu$ & 0.28 \\
\hline $\mathrm{E}_{\mathrm{c}}(\mathrm{MPa})$ & 35417.5 & k & 0.0028 \\
\hline$\gamma_{c}\left(k N / m^{3}\right)$ & 25 & \multirow[t]{6}{*}{$\delta(\mathrm{mm})$} & \multirow[t]{6}{*}{7} \\
\hline Slump (cm) & $5-9$ & & \\
\hline $\begin{array}{l}\text { Service life } \\
\text { (years) }\end{array}$ & 50 & & \\
\hline CAA & III & & \\
\hline $\begin{array}{l}\text { Temperature } \\
\left({ }^{\circ} \mathrm{C}\right)\end{array}$ & 20 & & \\
\hline Humidity (\%) & 75 & & \\
\hline
\end{tabular}

the results will not be the same as if the true cross-section were used. A more precise representation could have been used via the custom "Section Definition" option available in Robot.

The fact that it is impossible for any add-in to consider structures built with construction phases means that the model had to suffer some simplifications. The cross-beams at the supports and midspan were not considered in the model (they are replaced by concentrated loads on the beams) and the slab is defined as a "cladding", which serves only to distribute loads and does not add to the structure's stiffness. These simplifications are necessary since the beams are in fact prestressed prior to being hoisted and therefore the entire prestressing load is resisted by the isolated beam. If the cross-beams and the slab added to the stiffness of the model, they would absorb significant portions of the prestress load from the beam, leading to imprecise results.

The dead loads are divided into two parts: the beams' self-weight and that of the slab, pavement (including future repaving) and concrete barriers. The beams' self-weight load is applied on the structure as soon as the first phase of prestressing takes place. The remainder is assumed to all take place when the concrete is 28 days old. The live load is the TB-45 described in NBR 7188 [12], with a dynamic factor as per item 7.2.1.2 of NBR 7187 [13]. This must be done by the user (via a load combination) since Prestress has no way of knowing a priori whether such load factoring must take place. Figure [13] presents Prestress' output in .xlsx format. The stresses and SLS checks are presented for each section at each phase (the results of the third phase are omitted in this article). As can be observed in Section 6 during the last phase, whenever one of the

Figure $13 a-$ Results of Santa Isabel Viaduct

\begin{tabular}{|c|c|c|c|c|c|c|c|c|c|c|c|c|c|c|}
\hline \multirow{3}{*}{ Seçăo } & \multicolumn{3}{|c|}{ Momentos (kNm) } & \multicolumn{2}{|c|}{$\Delta$ Protensão } & \multicolumn{3}{|c|}{$\sigma$ Solicitantc $\left(\mathrm{MN} / \mathrm{m}^{2}\right)$} & \multirow{3}{*}{$\begin{array}{l}\Delta \sigma \text { Prot } \\
\left(\mathrm{MN} / \mathrm{III}^{2}\right)\end{array}$} & \multicolumn{4}{|c|}{$\sigma$ | otal $\left(\mathrm{MN} / \mathrm{m}^{2}\right)$} & \multirow{3}{*}{ Verlficar } \\
\hline & \multirow{2}{*}{$\Delta$ Perm } & \multicolumn{2}{|c|}{ Acidental } & \multirow{2}{*}{$\mathrm{M}(\mathrm{kN} \mathrm{m})$} & \multirow{2}{*}{$N(k N)$} & \multirow{2}{*}{$\Delta$ Perm } & \multicolumn{2}{|c|}{ Acidental } & & \multirow{2}{*}{$\begin{array}{c}\text { Perm + } \\
\text { Proll }\end{array}$} & \multicolumn{3}{|c|}{ Perm + Prot + Acidental } & \\
\hline & & + & & & & & Max & Min & & & ELS D & ELSF & tLS Ct & \\
\hline \multirow{2}{*}{$1 \frac{\text { Sup }}{\operatorname{lnf}}$} & \multirow{2}{*}{1.6} & \multirow{2}{*}{0.0} & \multirow{2}{*}{0.0} & \multirow{2}{*}{-25.7} & \multirow{2}{*}{3976.8} & 0.00 & 0.00 & 0.00 & -5.23 & -5.23 & -4.97 & -4.97 & $-G .04$ & - \\
\hline & & & & & & 0.00 & 0.00 & 0.00 & -5.36 & -5.36 & -5.09 & -5.09 & -6.19 & - \\
\hline \multirow{2}{*}{$2 \frac{\text { Sup }}{\operatorname{lnf}}$} & \multirow{2}{*}{1112.2} & \multirow{2}{*}{0.0} & \multirow{2}{*}{0.0} & \multirow{2}{*}{-1985.3} & \multirow{2}{*}{1111.3} & -3.65 & 0.00 & 0.00 & -0.34 & -3.99 & -3.97 & -3.97 & -4.04 & - \\
\hline & & & & & & 3.73 & 0.00 & 0.00 & -10.72 & -6.99 & -6.45 & -6.45 & -8.65 & - \\
\hline \multirow{2}{*}{$3 \frac{\text { Sup }}{\ln \mid}$} & \multirow{2}{*}{2510.6} & مחת & (1) & 37583 & ביר & 6.49 & 0.00 & 0.00 & 2.16 & 3.14 & 3.60 & 3.60 & 3.81 & \\
\hline & & 0.0 & 0.0 & -3258.3 & 4260.2 & 6.64 & 0.00 & 0.00 & -14.78 & -7.6 .5 & -6.9 .3 & -6.9 .3 & -9.86 & - \\
\hline sup & 32951 & (0) & م0 & -37855 & 43856 & -8.52 & 0.00 & 0.00 & 3.95 & -1.51 & $-1.3 i$ & -1.31 & -1.11 & - \\
\hline $4 \quad$ Inf & 1 & 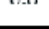 & T.X. & | & 4. & 8.71 & 0.00 & 0.00 & -15.84 & -7.13 & -6.34 & -6.34 & -9.59 & - \\
\hline Sup & 27650 & (0) & 00 & 20510 & $4005-$ & -9.74 & 0.00 & 0.00 & 4.10 & -5.64 & -5.44 & -5.44 & -5.84 & - \\
\hline Int & $3 / 65.5$ & 0.0 & 0.0 & $-3851 . J$ & 4405.6 & 9.96 & 0.00 & 0.00 & -16.05 & -6.09 & -5.20 & -5.29 & -8.58 & - \\
\hline 6 Sup & 39228 & 0.0 & 00 & -38126 & 4361.3 & -10.14 & 0.00 & 0.00 & 4.06 & -6.09 & -5.89 & -5.89 & -6.79 & - \\
\hline $6 \overline{\operatorname{lnf}}$ & & & & & & 10.37 & 0.00 & 0.00 & -15.88 & -5.51 & -1.72 & -1.72 & -7.97 & - \\
\hline Sup & 37659 & Oח & 00 & 38519 & $M 05-6$ & -9.74 & 0.00 & 0.00 & 4.10 & -5.64 & -5.44 & -5.44 & -5.84 & - \\
\hline Inf & $3 / 03.9$ & 0.0 & 0.0 & -3831.9 & T103.0 & 9.96 & 0.00 & 0.00 & -16.05 & -6.09 & -5.29 & -5.29 & -8.58 & - \\
\hline Sup & 37951 & חת & م00 & 3785 & 12856 & 8.52 & 0.00 & 0.00 & 3.95 & 4.57 & 4.37 & 4.37 & 4.77 & \\
\hline $\mathrm{InI}$ & 3295.1 & 0.0 & 0.0 & $-3 / 85.4$ & 4385.6 & 8.71 & 0.00 & $0 . \Omega 0$ & -1.5 .84 & -7.13 & -6.34 & -6.34 & -9.59 & - \\
\hline S Sup & 2510.5 & 0 & 00 & -3253.3 & 42602 & 6.49 & 0.00 & 0.00 & 2.16 & $3 . / 4$ & 3.60 & 3.60 & 3.81 & \\
\hline Inf & & & & & & G.G4 & 0.00 & 0.00 & -14.28 & -7.65 & $-G .93$ & -6.93 & $-9.8 \mathrm{C}$ & - \\
\hline $10^{\text {Sup }}$ & 1412.2 & 0.0 & 0.0 & -1985.3 & 4111.3 & -3.65 & 0.00 & 0.00 & -0.34 & -3.99 & -3.97 & -3.97 & -4.04 & - \\
\hline $10 \mathrm{Int}$ & 1412.2 & 0.0 & 0.0 & $\mid-1983.3$ & 4111.3 & 3.73 & 0.00 & 0.00 & -10.72 & -6.99 & -6.45 & -6.45 & -8.65 & - \\
\hline 11 Sup & 1.6 & 0.0 & 0.0 & -25.7 & 3076.8 & $0.0 n$ & ח. ח. & 0.00 & -5.23 & -5.23 & -4.97 & -4.97 & -6.04 & - \\
\hline Inf & 1.0 & 0.0 & 0.0 & & & 0.00 & 0.00 & 0.00 & -5.36 & -5.36 & -5.09 & -5.09 & -6.19 & - \\
\hline
\end{tabular}

First phase (after prestressing of first cables, $t=5$ days) 
Figure 13b-Results of Santa Isabel Viaduct

\begin{tabular}{|c|c|c|c|c|c|c|c|c|c|c|c|c|c|c|c|}
\hline \multirow{3}{*}{\multicolumn{2}{|c|}{ Scçāo }} & \multicolumn{3}{|c|}{ Momentos (kNm) } & \multicolumn{2}{|c|}{ A Proten รäก } & \multicolumn{3}{|c|}{$\sigma$ Solicitante $\left(\mathrm{MN} / \mathrm{m}^{2}\right)$} & \multirow{3}{*}{$\begin{array}{l}\Lambda \sigma \mathrm{Prot} \\
\left(\mathrm{MN} / \mathrm{m}^{2}\right)\end{array}$} & \multicolumn{4}{|c|}{$\sigma$ Tofal $\left(\mathrm{MN} / \mathrm{m}^{2}\right)$} & \multirow{3}{*}{ Vcritica } \\
\hline & & \multirow{2}{*}{$\Delta$ Perm } & \multicolumn{2}{|c|}{ Acidental } & \multirow{2}{*}{$\mathrm{M}(\mathrm{kNm})$} & \multirow{2}{*}{$N(\mathrm{kN})$} & \multirow{2}{*}{$\Delta$ Perm } & \multicolumn{2}{|c|}{ Acidental } & & \multirow{2}{*}{$\begin{array}{c}\text { Perm + } \\
\text { Prot }\end{array}$} & \multicolumn{3}{|c|}{ Perm I Prot I Acidental } & \\
\hline & & & + & - & & & & $\operatorname{Max}$ & Min & & & ELS-D & ELS-F & ELS-CE & \\
\hline \multirow{2}{*}{1} & \multirow{2}{*}{$\begin{array}{l}\text { Sup } \\
\text { Inf }\end{array}$} & \multirow{2}{*}{-5.3} & \multirow{2}{*}{61.5} & \multirow{2}{*}{0.0} & \multirow{2}{*}{-1342.9} & \multirow{2}{*}{5739.4} & 0.01 & 0.00 & -0.16 & -4.16 & -9.38 & -8.91 & -8.91 & -11.00 & - \\
\hline & & & & & & & -0.01 & 0.16 & 0.00 & -11.19 & -16.56 & -15.68 & -15.65 & -19.12 & - \\
\hline \multirow{2}{*}{2} & \multirow{2}{*}{ Sup } & \multirow{2}{*}{2158.7} & \multirow{2}{*}{978.6} & \multirow{2}{*}{0.0} & \multirow{2}{*}{-3295.0} & \multirow{2}{*}{5895.4} & -5.58 & 0.00 & -2.53 & 0.68 & -8.90 & -8.88 & -8.88 & -11.44 & - \\
\hline & & & & & & & b./1 & 2.59 & 0.00 & -16.36 & $-1 / .8 .1$ & -13.10 & -15.18 & -22.06 & - \\
\hline & Sup & & & & & & -9.98 & 0.00 & -4.64 & 2.91 & -10.80 & -10.52 & -10.52 & -15.73 & - \\
\hline 3 & \begin{tabular}{|l|l|}
$\operatorname{Inf}$ \\
\end{tabular} & 3860.6 & 1793.7 & 0.0 & -4252.3 & |6073.4 & 10.21 & 4.74 & 0.00 & -19.32 & -16.76 & -13.66 & -12.71 & -21.97 & - \\
\hline 4 & Sup & & & & & & -13.17 & 0.00 & -6.27 & 4.34 & -13.39 & -12.98 & -12.98 & -20.08 & - \\
\hline 4 & \begin{tabular}{|l|l|}
$\operatorname{Inf}$ \\
\end{tabular} & 5091.8 & 2425.8 & 0.0 & -4896.6 & 6253.2 & 13.46 & 6.41 & 0.00 & -21.27 & -14.94 & -11.16 & -9.87 & -70.69 & - \\
\hline 5 & Sup & 5845,6 & 28017 & 00 & 5283.3 & 6379.5 & -15.12 & 0.00 & -7.24 & 5.17 & -15.58 & -15.12 & -15.12 & -23.29 & - \\
\hline & $\operatorname{Inf}$ & & & & 5283.5 & & 15.46 & 7.41 & 0.00 & -22.46 & -13.09 & -8.94 & -7.46 & -19.06 & - \\
\hline & sup & & & & & & -15.81 & 0.00 & -7.47 & 5.27 & -16.63 & -16.17 & -16.17 & -24.57 & - \\
\hline 6 & $\operatorname{Inf}$ & 6115.7 & 2888.8 & 0.0 & -5313.6 & 6365.5 & 16.17 & 7.64 & 0.00 & -27.52 & $-11.8 \mathrm{6}$ & -7.65 & -6.12 & -17.81 & - \\
\hline 7 & Sup & 58456 & 28001 & 00 & 52833 & 6379.5 & -15.12 & 0.00 & -7.24 & 5.17 & -15.58 & -15.12 & -15.12 & -23.29 & - \\
\hline & $\operatorname{Inf}$ & & & & 5283.3 & & 15.46 & 7.40 & 0.00 & -22.46 & -13.09 & -8.95 & -7.46 & -19.06 & - \\
\hline 8 & Suf & 50918 & 24278 & 0.0 & -48965 & 6253.1 & -13.17 & 0.00 & -6.28 & 4.34 & -13.39 & -17.98 & -12.98 & -20.09 & - \\
\hline & Inf & & & & & & 13.46 & 6.47 & 0.00 & -21.27 & -14.94 & -11.16 & -9.87 & -70.69 & - \\
\hline c & Sup & 38606 & & & & & -9.98 & 0.00 & -4.64 & 2.91 & -10.80 & -10.52 & -10.52 & -15.72 & - \\
\hline 9 & $\operatorname{Inf}$ & 3860.6 & 1793.0 & 0.0 & 4252.2 & $60 / 3.3$ & 10.21 & 4.74 & 0.00 & -19.32 & -16.76 & -13.66 & -12.71 & -21.97 & - \\
\hline 10 & Sup & & & & & & -5.58 & $0 . \Omega 0$ & -7.53 & 0.68 & $-8.9 n$ & -8.8 .8 & -8.88 & -11.44 & - \\
\hline 10 & \begin{tabular}{|l|}
$\operatorname{Inf}$ \\
\end{tabular} & 2158.7 & 978.7 & 0.0 & -3294.9 & 5895.3 & 5.71 & 2.59 & 0.00 & -16.56 & -17.84 & -15.70 & -15.18 & -72.06 & - \\
\hline 11 & sup & 5.3 & 61.4 & 0.0 & 13429 & 5739.4 & 0.01 & 0.00 & -0.16 & -4.16 & -9.38 & -8.91 & -8.91 & -10.99 & - \\
\hline 11 & \begin{tabular}{|l|}
$\operatorname{Inf}$ \\
\end{tabular} & 5.3 & 61.4 & 0.0 & 1342.9 & $5 / 39.4$ & -0.01 & 0.16 & $0 . m n$ & -11.19 & -16.56 & -15.68 & -15.65 & -19.12 & - \\
\hline
\end{tabular}

B Second phase (after prestressing of remaining cables and placing of slab and other loads, $t=28$ days)

Figure $13 c-$ Results of Santa Isabel Viaduct

\begin{tabular}{|c|c|c|c|c|c|c|c|c|c|c|c|c|c|c|}
\hline \multirow{3}{*}{ Seçẵo } & \multicolumn{3}{|c|}{ Momcntos $(\mathrm{kNm})$} & \multicolumn{2}{|c|}{$\Delta$ Protensão } & \multicolumn{3}{|c|}{$\sigma$ Solicitantc $\left(\mathrm{MN} / \mathrm{m}^{2}\right)$} & \multirow{3}{*}{$\begin{array}{l}\Delta \sigma \text { Prot } \\
\left(\mathrm{MN} / \mathrm{m}^{2}\right)\end{array}$} & \multicolumn{4}{|c|}{$\sigma \mid$ otal $\left(\mathrm{MN} / \mathrm{m}^{2}\right)$} & \multirow{3}{*}{ Verlficar } \\
\hline & \multirow{2}{*}{$\Delta P$ erm } & \multicolumn{2}{|c|}{ Acidental } & \multirow{2}{*}{$\mathrm{M}(\mathrm{kNm})$} & \multirow{2}{*}{$\mathrm{N}(\mathrm{kN})$} & \multirow{2}{*}{$\Delta$ Perm } & \multicolumn{2}{|c|}{ Acidental } & & \multirow{2}{*}{ 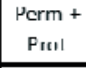 } & \multicolumn{3}{|c|}{ Perm + Prot + Acidental } & \\
\hline & & + & & & & & Max & Min & & & ELS D & ELSt & ELS CL & \\
\hline \multirow{2}{*}{$1 \frac{\text { Sup }}{\operatorname{Inf}}$} & \multirow{2}{*}{0.0} & \multirow{2}{*}{61.5} & \multirow{2}{*}{0.0} & \multirow{2}{*}{111.0} & \multirow{2}{*}{-721.2} & 0.00 & 0.00 & $-0.1 \mathrm{G}$ & 0.67 & -7.77 & -7.38 & -7.38 & -9.13 & - \\
\hline & & & & & & 0.00 & 0.16 & 0.00 & 1.25 & -13.21 & -12.53 & -12.50 & -15.29 & - \\
\hline \multirow{2}{*}{$2 \frac{\text { Sup }}{\operatorname{lnf}}$} & \multirow{2}{*}{0.0} & \multirow{2}{*}{978.6} & \multirow{2}{*}{0.0} & \multirow{2}{*}{114.1} & \multirow{2}{*}{-807.9} & 0.00 & 0.00 & -2.53 & -0.07 & -9.11 & -9.11 & -9.11 & -11.65 & - \\
\hline & & & & & & 0.00 & 2.59 & 0.00 & 2.25 & -12.01 & -10.16 & -9.64 & -15.33 & - \\
\hline \multirow{2}{*}{$3 \frac{\text { Sup }}{\operatorname{lnt} I}$} & \multirow{2}{*}{0.0} & \multirow{2}{*}{1793.7} & 0.0 & 655.7 & -888.2 & 0.00 & 0.00 & 4.64 & 0.51 & 12.06 & 11.84 & 11.84 & 16.92 & \\
\hline & & & & 1033.1 & -808.1 & 0.00 & 4.74 & 0.00 & 7.97 & -9.54 & -6.80 & -5.8 .5 & -13.63 & - \\
\hline sup & 0.0 & 2425. & 00 & 767.7 & -9356 & 0.00 & 0.00 & -6.21 & -0.11 & $-15,13$ & -11.81 & -11.81 & $-21 . / 3$ & - \\
\hline $\ln$ & 0.10 & $44 \% .6$ & 0.0 & 6.8. & -4.7 .6 .6 & 0.00 & 6.41 & 0.00 & 3.27 & -7.17 & -3.78 & -2.50 & -11.72 & - \\
\hline Sup & 0.0 & 2801.7 & 0.0 & 800.1 & $-9<2.3$ & 0.00 & 0.00 & -7.24 & -0.82 & -17.45 & -17.08 & -17.08 & -25.06 & - \\
\hline Int & & 2801.7 & 0.0 & 800.1 & $-3242,3$ & 0.00 & 7.41 & 0.00 & 3.37 & -5.34 & -1.58 & -0.10 & -10.11 & - \\
\hline Sup & 0.0 & 2888.8 & 0.0 & & & 0.00 & 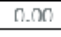 & -7.47 & -0.81 & -18.45 & -18.07 & -18.07 & -26.29 & - \\
\hline $\operatorname{Inf}$ & 0.0 & 2888.8 & 0.0 & 787.5 & $-923 . I$ & 0.00 & 7.61 & 0.00 & 3.31 & -1.38 & -0.51 & 0.99 & -9.17 & - \\
\hline 7 Sup & 0.0 & 2880,1 & 0.0 & 880,1 & $-9 / 2.3$ & 0.00 & 0.00 & -7.24 & -0.82 & -17.45 & -17.08 & -17.08 & -25.06 & - \\
\hline $\operatorname{lnf}$ & & 2800.1 & 0.0 & 800.1 & -912.3 & 0.00 & 7.40 & 0.00 & 3.37 & -5.34 & -1.58 & -0.10 & -10.11 & - \\
\hline Sup & 0.0 & & & 767.7 & & 0.00 & 0.00 & 6.28 & 0.74 & 15.13 & 14.81 & 14.81 & 21.74 & \\
\hline $\mathrm{InII}$ & 0.0 & 2427.8 & 0.0 & 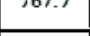 & -933.1 & 0.00 & 6.47 & 0.00 & 3.77 & -7.17 & -3.78 & -2.49 & -11.72 & - \\
\hline Sup & 0.0 & 1793.0 & 0.0 & 655.7 & -8ి8ి.2 & 0.00 & 0.00 & 4.64 & 0.51 & 12.01 & 11.84 & 11.84 & 16.92 & \\
\hline $\operatorname{lnf}$ & & & & & & 0.00 & 4.74 & 0.00 & 2.92 & -9.54 & -6.80 & -5.85 & -13.63 & - \\
\hline 10 Sup & 0.0 & 978.7 & 0.0 & 444.5 & -808.0 & 0.00 & 0.00 & -2.53 & -0.07 & -9.11 & -9.11 & -9.11 & -11.65 & - \\
\hline sup & & & & & & 0.00 & $\frac{2.50}{n .0 n}$ & $\frac{0.00}{-0.16}$ & $\frac{2.25}{0.67}$ & $\frac{-12.01}{-7.77}$ & $\frac{-10.16}{-7.38}$ & $\begin{array}{l}-9.64 \\
-7.38\end{array}$ & -9.13 & - \\
\hline$\overline{\mathrm{Inf}}$ & 0.0 & 61.4 & 0.0 & 111.0 & -721.2 & 0.00 & 0.16 & 0.00 & 1.25 & -13.21 & -12.53 & $\begin{array}{l}12.50 \\
\end{array}$ & -15.29 & - \\
\hline
\end{tabular}

C Last phase (end of service life, $t=18250$ days) 
Figure 14 - Plan and cross-section of Guarita Viaduct - North. Reprinted from Cerne Engenharia (14)
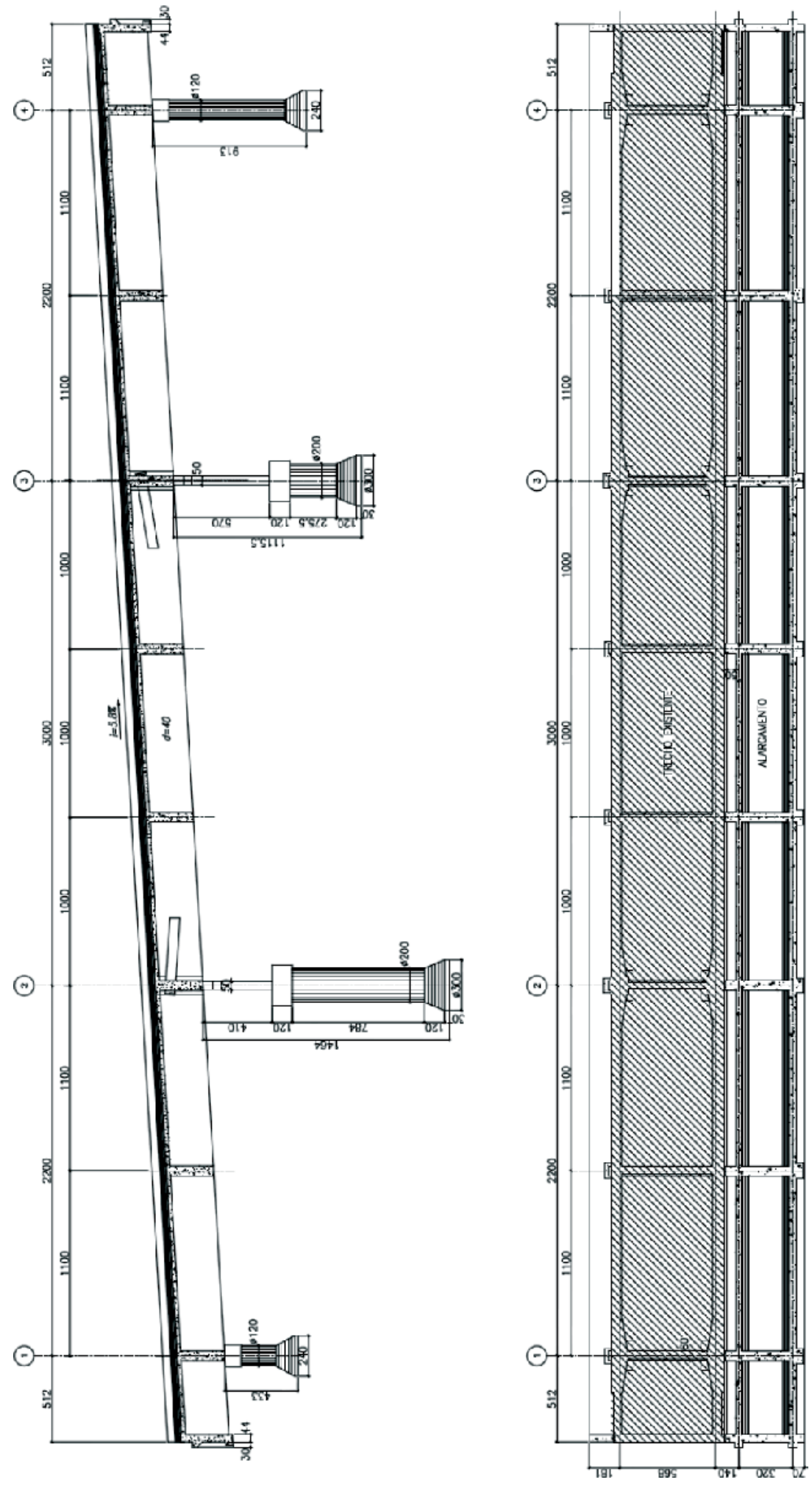
SLS checks fails, a flag is raised pointing it out. In this case, the ELS-D condition was not satisfied, since the concrete is in tension under almost-permanent live loads. The file also contains the estimated elongation of the cables prior to anchorage slippage losses (not shown in this article). As with the input window, the units adopted in this results file are taken from the Robot model.

As mentioned in Section [2.2], Prestress also outputs the equiva- lent loads for each phase. This allows the user to include the effect of the prestress for other calculations, such as that of the necessary shear reinforcement.

\subsection{Guarita Viaduct - North}

The project of Guarita Viaduct - North [14] is aimed at

\section{Figure 15 - Prestressing data and cross-section of Guarita Viaduct - North. Reprinted from Cerne Engenharia (14)}
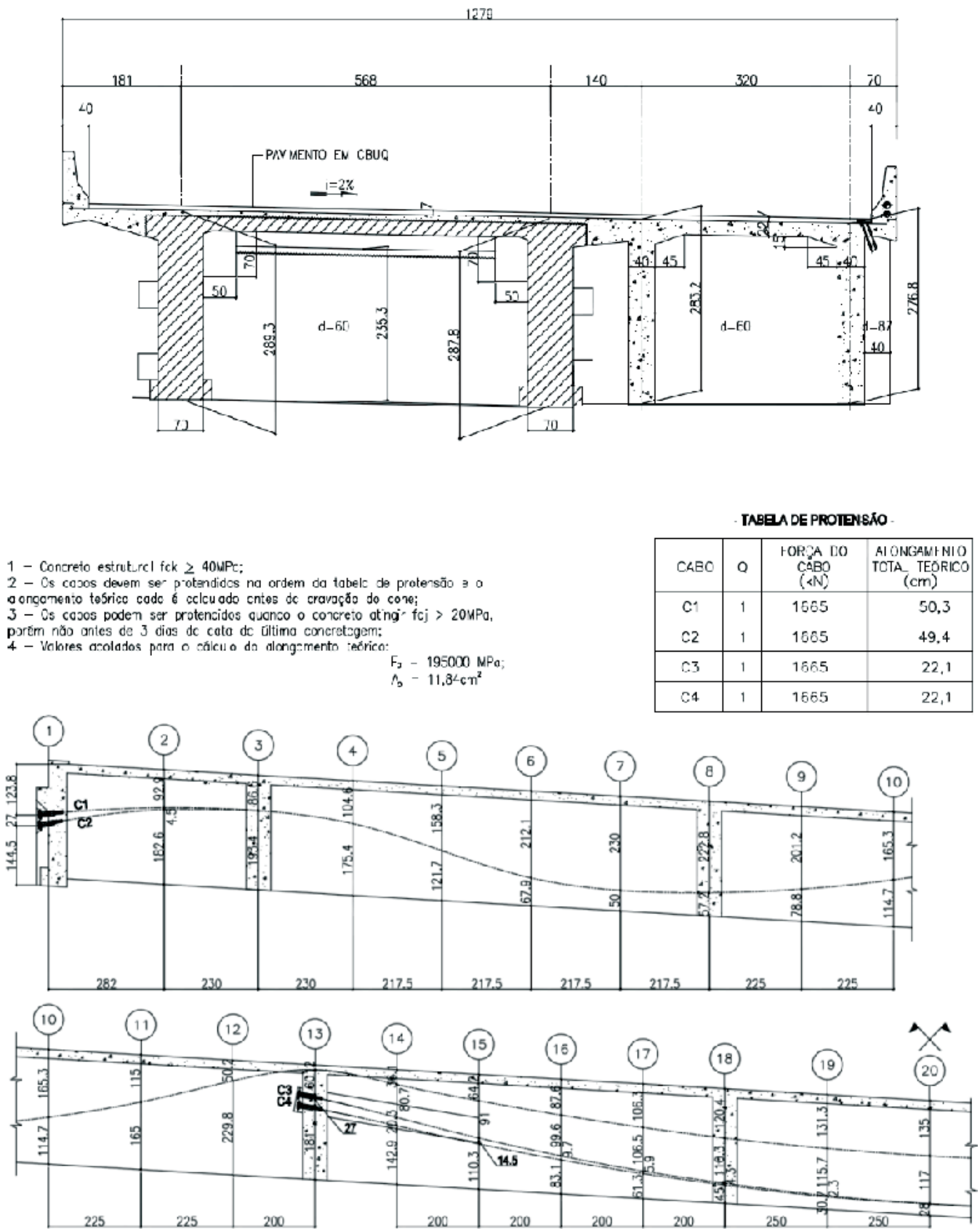
reinforcing and widening an existing statically-indeterminate structure with three spans and short cantilevers at each end. The crosssection is composed of four cast-in-place concrete beams, two of which are from the existing structure and two are a part of the widening project. The new beams are prestressed with bonded posttensioned cables. Figures [14] and [15] and Table [2] contain the

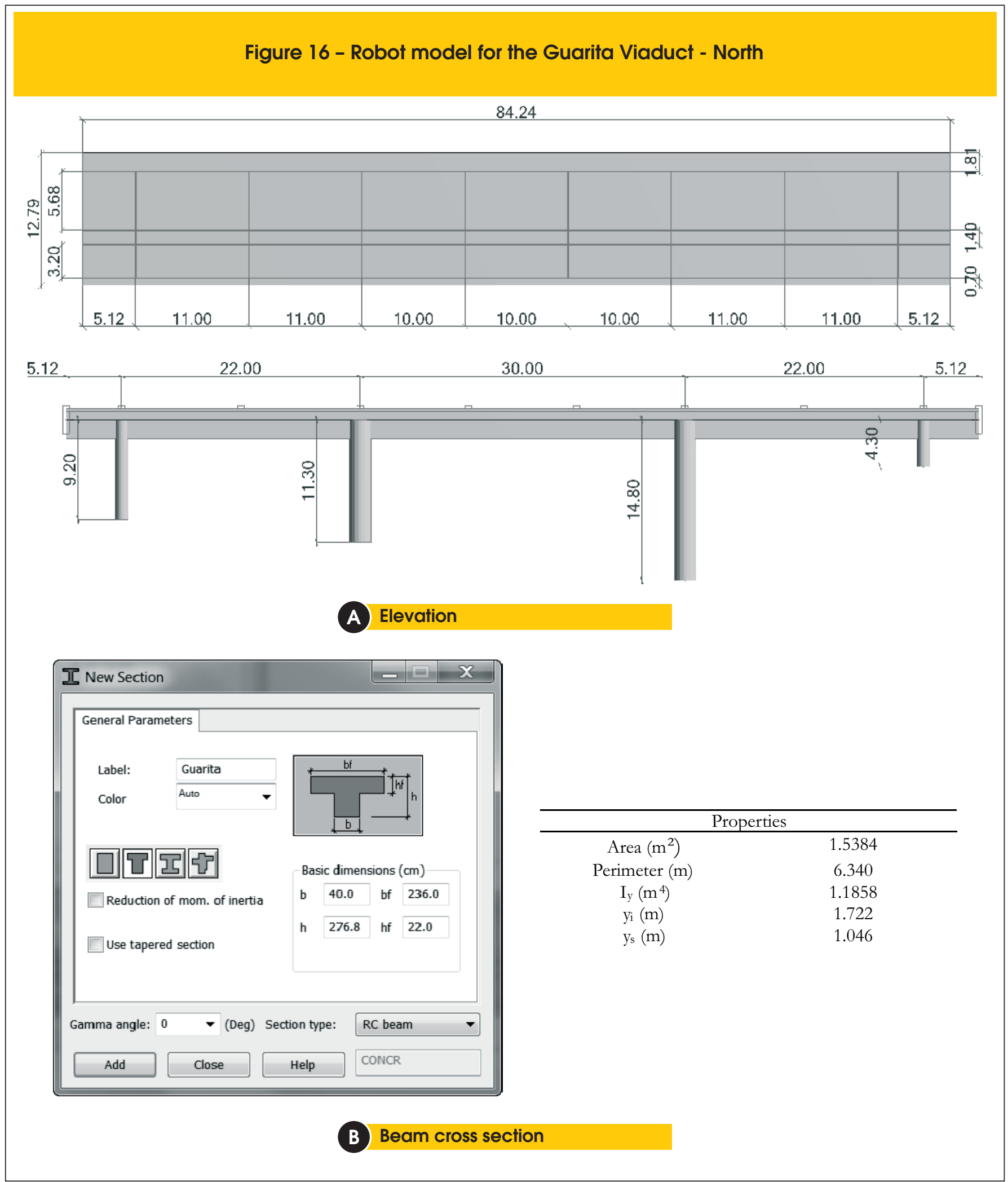


information on the prestressing of the beams. As with most current Brazilian bridges the chosen live load is the TB-45 [12].

The adopted Robot model is shown in Figure [16]. The real boundary conditions in this bridge are quite different from those seen in the example of Section [3.1]. The entire structure of this viaduct is monolithic. The beams are supported by the pillars via Freyssinet hinges, which allow the differential rotation of the beams in relation to the pillars but do not allow for differential displacements. For this reason the entire structure, including pillars, was considered in this model. This way, any interference the remainder of the structure may have in the behavior of the prestress will be taken into account.

The slab, however, had to be considered as a simple "cladding", with no stiffness. This occurs for the same reason as described in Section [3.1]: a slab with stiffness would resist the prestress' compression of the beam, whose cross-section already includes the slab's effective flange width, therefore reducing the effective stresses on the beam itself.

The dead loads here are separated into two groups: one applied once the cables are jacked, composed of the self-weight of the beams (including cross-beams) and the slab; and another which contains the pavement and concrete-barrier loads which is applied after 28 days. The live loading is identical to that described in Section [3.1].

Figure [17] presents the results file. The results are not exactly symmetric due to the asymmetry of the pillars and therefore of the structure's center of rigidity. However, for brevity's sake, only results up to section 20 (midspan) are shown in this article. Observe how section 13, which represents the supports of the main span, presents results of the points to the left (13E) and right (13D). This occurs because of the stress discontinuity due to the intermediate cables which anchor there. If a section presents a stress discontinuity, be that due to substantial concentrated loads or cross-section discontinuities, then stress calculations and SLS checks are always shown for the points immediately to the left and to the right.

\section{Conclusions}

Prestress, the software developed for this article, allows the user to perform serviceability limit state checks on post-tensioned beams with bonded tendons in a simple and expedient form, therefore also enabling the iteration between multiple different prestressing solutions. There are multiple different tools which perform similar tasks to Prestress, such as midas Civil $^{\circledR}$, SAP $2000^{\circledR}$, ADAPT-ABI ${ }^{\circledR}$, ADAPT-PTI $\mathbf{R C}^{\circledR}$, and RAPT ${ }^{\circledR}$, among others. All were developed by professional teams and most contain tools which are far more advanced than those demonstrated here. Only Prestress, however, works directly in tandem with Robot and therefore allows for a far greater interoperability with the rest of the Autodesk package (Revit ${ }^{\circledR}$, for instance). As previously stated, though the BIM philosophy does not demand the use of a closed environment, adopting a single company's product package does indeed at present allow for an easier implementation of BIM. Prestress stands as a (small) first step towards including the calculation of prestressed beams within this philosophy.

Working within Robot also grants Prestress the ability to naturally consider all the boundary conditions surrounding the beam. As described above, such considerations are essential for a precise calculation of the true effects of prestress on a beam and on the remainder of the structure.

This software is evidently nothing more than a tool to be placed in one's toolbelt. As with any other software, it runs the inescapable

\section{Table 2 - Properties of Guarita Viaduct - North}

\begin{tabular}{|c|c|c|c|}
\hline \multicolumn{2}{|c|}{ Properties } & \multicolumn{2}{|c|}{ Limited prestress } \\
\hline Area $\left(m^{2}\right)$ & 1.5722 & Steel & CP-190 RB \\
\hline Perimeter (m) & 10.13 & $f_{p+k}\left(k N / c^{2}\right)$ & 190 \\
\hline $\mathrm{I}_{\mathrm{y}}\left(\mathrm{m}^{4}\right)$ & 1.2313 & $f_{\text {pyk }}\left(k N / \mathrm{cm}^{2}\right)$ & 170 \\
\hline$y_{i}(m)$ & 1.011 & $\sigma_{p i}\left(k N / c^{2}\right)$ & 140.6 \\
\hline$y_{s}(m)$ & 1.757 & $E_{p}\left(k N / m m^{2}\right)$ & 195 \\
\hline Concrete type & CPV-ARI & $A_{p}\left(m m^{2}\right)$ & 1184.0 \\
\hline$f_{c k}(M P a)$ & 40 & $\mu$ & 0.28 \\
\hline $\mathrm{E}_{\mathrm{c}}(\mathrm{MPa})$ & 35417.5 & k & 0.0028 \\
\hline$\gamma_{c}\left(k N / m^{3}\right)$ & 25 & \multirow[t]{6}{*}{$\delta(\mathrm{mm})$} & \multirow[t]{6}{*}{7} \\
\hline Slump (cm) & $5-9$ & & \\
\hline $\begin{array}{l}\text { Service life } \\
\text { (years) }\end{array}$ & 50 & & \\
\hline CAA & III & & \\
\hline $\begin{array}{l}\text { Temperature } \\
\left({ }^{\circ} \mathrm{C}\right)\end{array}$ & 25 & & \\
\hline Humidity (\%) & 75 & & \\
\hline
\end{tabular}

risk of "garbage in, garbage out". If the user presents it with incorrect data (including, and perhaps most importantly, the structural model), the results will be equally incorrect. It is therefore essential that the add-in be used by an engineer who is familiar with the concepts behind prestress and who is capable of analyzing the results with a critical eye and of recognizing that which is incorrect.

\section{References}

[1] DE RIET, M. Myth buster: Revit \& IFC, part 3. Available at: <http://www.augi.com/library/myth-buster-revit-ifc-part-3>. Access on 2 set. 2014, 15:30.

[2] AUTODESK. Autodesk Robot Structural Analysis Professional 2015: Robot object model, 2014.

[3] BORTONE, T. P. Avaliação das tensões no estado limite de serviço em seções de concreto protendido. Belo Horizonte, MG: 2014. Originally presented as master's thesis, Universidade Federal de Minas Gerais, 2014.

[4] LAZZARI, P. M., et al. Automation of the evaluation of bonded and unbonded prestressed concrete beams, according to brazilian and french code specifications. IBRACON Structures and Materials Journal, v. 6, n. 1, p. 13 - 54, Fev. 2013. Avaiable at: <http://www.revistas.ibracon.org.br/index.php/ riem/article/view/341/337>. Access on 23 apr. 2015, 21:30.

[5] PCI COMMITTEE ON PRESTRESS LOSSES. Recommendations for estimating prestress losses. PCl Journal, v. 17, n. 2, p. 17-31, Mar 1975.

[6] LIN, T. Y. Design of prestressed concrete structures. 2nd. ed. New York, United States of America: John Wiley \& Sons, Inc., 1981. 
[7] AALAMI, B. O. Critical milestones in development of posttensioned buildings. Concrete International, v. 29, n. 10, p. 52 - 56, Oct. 2007. Avaiable at: <http://www.adaptsoft.com/ resources/Cl_article_Oct_2007.pdf>. Access on 31 oct. 2014, 23:00.

[8] ASSOCIAÇÃO BRASILEIRA DE NORMAS TÉCNICAS. ABNT NBR 6118: Projeto de estruturas de concreto procedimento. Rio de Janeiro: ABNT, 2014. ISBN 978-8507-04941-8.

[9] CHAUSSIN, R.; FUENTES, A.; LACROIX, R.; PERCHAT, J. La précontrainte. 1ère. ed. Paris, França: Presses de l'école nationale des ponts et chaussées, 1992. ISBN 2-85978-180-3.

[10] ASSOCIAÇÃO BRASILEIRA DE NORMAS TÉCNICAS. ABNT NBR 8681: Ações e segurança nas estruturas - Procedimento. Rio de Janeiro: ABNT, 2003.

[11] CERNE ENGENHARIAE PROJETOS. Executive project of the Santa Isabel Viaduct, 2013. 15 blueprints, 1 calculation log.

[12] ASSOCIAÇÃO BRASILEIRA DE NORMAS TÉCNICAS. ABNT NBR 7188: Carga móvel em ponte rodoviária e passarela de pedestre. Rio de Janeiro: ABNT, 2013.

Figure 17a - Results of Guarita Viaduct - North

\begin{tabular}{|c|c|c|c|c|c|c|c|c|c|c|c|c|c|c|c|}
\hline \multirow{3}{*}{\multicolumn{2}{|c|}{ Seçäo }} & \multicolumn{3}{|c|}{ Momentos $(\mathrm{kNm})$} & \multicolumn{2}{|c|}{$\Delta$ Protensão } & \multicolumn{3}{|c|}{$\sigma$ Solicitante $\left(\mathrm{MN} / \mathrm{m}^{2}\right)$} & \multirow{3}{*}{$\begin{array}{r}\Delta \sigma \text { Prot } \\
\left(\mathrm{MN} / \mathrm{m}^{2}\right)\end{array}$} & \multicolumn{4}{|c|}{$\sigma$ Total $\left(\mathrm{MN} / \mathrm{m}^{2}\right)$} & \multirow{3}{*}{ Verificar } \\
\hline & & \multirow{2}{*}{$\Delta$ Perm } & \multicolumn{2}{|c|}{ Acidental } & \multirow{2}{*}{$\mathrm{M}(\mathrm{kNm})$} & \multirow{2}{*}{$\mathrm{N}(\mathrm{kN})$} & \multirow{2}{*}{$\Delta$ Perm } & \multicolumn{2}{|c|}{ Acidental } & & \multirow{2}{*}{$\begin{array}{c}\text { Perm + } \\
\text { Prot }\end{array}$} & \multicolumn{3}{|c|}{ Perm + Prot + Acidental } & \\
\hline & & & + & - & & & & $\overline{M a x}$ & Min & & & ELS-D & ELS-F & ELS-CE & \\
\hline \multirow{2}{*}{\multicolumn{2}{|c|}{\begin{tabular}{l|l|}
\multirow{2}{*}{1} & Sup \\
\cline { 2 - 3 } & Inf
\end{tabular}}} & \multirow{2}{*}{-17.1} & \multirow{2}{*}{0.0} & \multirow{2}{*}{0.0} & & 22150 & 0.01 & 0.00 & 0.00 & -0.75 & -0.73 & -0.70 & -0.70 & -0.85 & - \\
\hline & & & & & -817.0 & 215.0 & -0.02 & 0.00 & 0.00 & -2.61 & -2.64 & -2.51 & -2.51 & -3.04 & - \\
\hline 2 & Sup & $=4211$ & קO & & & & 0.36 & 0.00 & 0.00 & -1.78 & -1.43 & -1.34 & -1.34 & -1.70 & - \\
\hline & Inf & -421.1 & 0.0 & 0.0 & 299.9 & 2353.8 & -0.60 & 0.00 & 0.00 & -1.10 & -1.70 & -1.65 & -1.65 & -1.87 & - \\
\hline & Sup & & & & & & 0.87 & 0.00 & 0.00 & -2.11 & -1.24 & -1.13 & -1.13 & -1.56 & - \\
\hline 3 & $\ln \mid$ & -1025.3 & 0.0 & 0.0 & 591.1 & 2469.7 & -1.47 & 0.00 & 0.00 & -0.76 & -2.23 & -2.19 & -2.19 & -2.35 & - \\
\hline 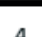 & Sup & 1540 & הח & החת & 4951 & ם ברכך & 0.13 & 0.00 & 0.00 & -1.87 & -1.74 & -1.64 & -1.64 & -2.03 & - \\
\hline 4 & Inf & -154.0 & 0.0 & 0.0 & 495.1 & 2227.9 & -0.22 & 0.00 & 0.00 & -0.74 & -0.96 & -0.92 & -0.92 & -1.07 & - \\
\hline$=$ & Sup & 4498 & 00 & 00 & $-49 r_{1}$ & 21006 & -0.38 & 0.00 & 0.00 & -0.82 & -1.20 & -1.16 & -1.16 & -1.32 & - \\
\hline 5 & Inf & 449.8 & 0.0 & 0.0 & -695.1 & 2160.6 & 0.65 & 0.00 & 0.00 & -2.40 & -1.76 & -1.64 & -1.64 & -2.13 & - \\
\hline 6 & Sup & 8310 & م0 & 0 & -18047 & 20831 & -0.70 & 0.00 & 0.00 & 0.17 & -0.53 & -0.52 & -0.52 & -0.54 & - \\
\hline & Inf & 831.0 & & 0.0 & -1804.7 & 2083.1 & 1.19 & 0.00 & 0.00 & -3.95 & -2.75 & -2.56 & -2.56 & -3.36 & - \\
\hline & Sup & & & & & & -0.84 & 0.00 & 0.00 & 0.26 & -0.58 & -0.57 & -0.57 & -0.59 & - \\
\hline 7 & $\operatorname{lnf}$ & 988.1 & 0.0 & 0.0 & -1811.6 & 1964.9 & 1.42 & 0.00 & 0.00 & -3.88 & -2.46 & -2.27 & -2.27 & -3.06 & - \\
\hline 8 & Sup & 0916 & (00 & 00 & 11867 & 18860 & -0.78 & 0.00 & 0.00 & -0.22 & -1.00 & -0.99 & -0.99 & -1.03 & - \\
\hline & $\operatorname{lnf}$ & 919.6 & 0.0 & 0.0 & -1186.7 & 1886.0 & 1.32 & 0.00 & 0.00 & -2.93 & -1.61 & -1.46 & -1.46 & -2.06 & - \\
\hline a & Sup & 4583 & م0 & 0 & -8263 & 14714 & -0.39 & 0.00 & 0.00 & -0.26 & -0.64 & -0.63 & -0.63 & -0.68 & - \\
\hline 9 & Inf & 458.3 & 0.0 & 0.0 & -826.3 & $14 / 1.4$ & 0.66 & 0.00 & 0.00 & -2.14 & -1.48 & -1.38 & -1.38 & -1.82 & - \\
\hline 10 & Sup & -2433 & م0 & החס & -1129 & 14061 & 0.21 & 0.00 & 0.00 & -0.87 & -0.61 & -0.57 & -0.57 & -0.74 & - \\
\hline & Inf & & & & & & -0.35 & 0.00 & 0.00 & -1.08 & -1.43 & -1.37 & -1.37 & -1.59 & - \\
\hline 11 & Sup & 11884 & م0 & (200 & 8960 & 2013 & 1.01 & 0.00 & 0.00 & -1.63 & -0.63 & -0.55 & -0.55 & -0.88 & - \\
\hline 11 & Inf & -1188.4 & 0.0 & 0.0 & 896.0 & 1345.3 & -1.71 & 0.00 & 0.00 & 0.41 & -1.29 & -1.27 & -1.27 & -1.31 & - \\
\hline & Sup & & & & & & 2.01 & 0.00 & 0.00 & -2.68 & -0.67 & -0.53 & -0.53 & -1.08 & - \\
\hline 12 & \begin{tabular}{|l|} 
Inf \\
\end{tabular} & -2377.1 & 0.0 & 0.0 & 2179.4 & 1282.1 & -3.41 & 0.00 & 0.00 & 2.30 & -1.12 & -1.00 & -1.00 & -1.23 & - \\
\hline 13E & Sup & -36202 & 00 & 0.0 & 27187 & 11335 & 3.07 & 0.00 & 0.00 & -3.04 & 0.03 & 0.18 & 0.18 & -0.44 & ELS-D \\
\hline $13 \mathrm{E}$ & \begin{tabular}{|l|}
$\operatorname{lnf}$ \\
\end{tabular} & -3620.2 & 0.0 & 0.0 & $2 / 18 . /$ & 1133.5 & -5.20 & 0.00 & 0.00 & 3.17 & -2.03 & -1.87 & -1.87 & -2.19 & - \\
\hline 132 & Sup & -36020 & & م0 & 32067 & 35191 & 3.05 & 0.00 & 0.00 & -5.00 & -1.95 & -1.70 & -1.70 & -2.73 & - \\
\hline 130 & Inf & -3602.0 & 0.0 & 0.0 & 3206.7 & 3519.1 & -5.17 & 0.00 & 0.00 & 2.32 & -2.86 & -2.74 & -2.74 & -2.97 & - \\
\hline & Sup & -21408 & ק0 & 00 & 19149 & 34270 & 1.81 & 0.00 & 0.00 & -3.86 & -2.04 & -1.85 & -1.85 & -2.64 & - \\
\hline 14 & Inf & -2140.8 & 0.0 & 0.0 & 1914.9 & 3437.0 & -3.07 & 0.00 & 0.00 & 0.52 & -2.56 & -2.53 & -2.53 & -2.58 & - \\
\hline 15 & Sup & 8448 & م0 & م0 & 7540 & 34526 & 0.72 & 0.00 & 0.00 & -2.88 & -2.17 & -2.02 & -2.02 & -2.61 & - \\
\hline 15 & \begin{tabular}{|l|l|}
$\operatorname{Inf}$ \\
\end{tabular} & -844.8 & 0.0 & 0.0 & 154.0 & 3452.6 & -1.21 & 0.00 & 0.00 & -1.16 & -2.37 & -2.32 & -2.32 & -2.55 & - \\
\hline & Sup & 263.5 & 00 & 00 & -1620 & 34766 & -0.22 & 0.00 & 0.00 & -2.12 & -2.35 & -2.24 & -2.24 & -2.67 & - \\
\hline 16 & \begin{tabular}{l|l|} 
Inf \\
\end{tabular} & 263.5 & 0.0 & 0.0 & -162.0 & 3476.6 & 0.38 & 0.00 & 0.00 & -2.49 & -2.11 & -1.99 & -1.99 & -2.50 & - \\
\hline 17 & Sup & 71827 & مח & ק0 & 8230 & 35076 & -1.00 & 0.00 & 0.00 & -1.57 & -2.58 & -2.50 & -2.50 & -2.82 & - \\
\hline 17 & \begin{tabular}{|l|l|}
$\ln$ \\
\end{tabular} & 1182.7 & 0.0 & 0.0 & 833.0 & 3507.6 & 1.70 & 0.00 & 0.00 & -3.48 & -1.78 & -1.60 & -1.60 & -2.32 & - \\
\hline 18 & Sup & 19111 & مח & 00 & 72027 & 35369 & -1.62 & 0.00 & 0.00 & -1.26 & -2.88 & -2.82 & -2.82 & -3.07 & - \\
\hline 18 & $\operatorname{Inf}$ & 1911.6 & 0.0 & 0.0 & -1277.7 & 3536.9 & 2.75 & 0.00 & 0.00 & -4.06 & -1.32 & -1.11 & -1.11 & -1.95 & - \\
\hline 19 & Sup & 23887 & م0 & م0 & -19256 & 34803 & -2.02 & 0.00 & 0.00 & -0.63 & -2.65 & -2.62 & -2.62 & -2.75 & - \\
\hline 19 & \begin{tabular}{|l|l|} 
Inf \\
\end{tabular} & 2388.1 & 0.0 & 0.0 & -1925.6 & 3480.3 & 3.43 & 0.00 & 0.00 & -5.03 & -1.60 & -1.35 & -1.35 & -2.38 & - \\
\hline 20 & Sup & 2543.1 & 0.0 & 0.0 & -2061.2 & 3401.7 & -2.15 & 0.00 & 0.00 & -0.47 & -2.62 & -2.60 & -2.60 & -2.69 & - \\
\hline & Inf & & & & & 3401.7 & 3.65 & 0.00 & 0.00 & 5.17 & 1.52 & -1.26 & -1.26 & 2.32 & \\
\hline
\end{tabular}

A First phase (after jacking of cables, $t=\mathbf{3}$ days) 
Figure 17b - Results of Guarita Viaduct - North

\begin{tabular}{|c|c|c|c|c|c|c|c|c|c|c|c|c|c|c|c|}
\hline \multirow{3}{*}{\multicolumn{2}{|c|}{ Seção }} & \multicolumn{3}{|c|}{ Momentos (kNm) } & \multicolumn{2}{|c|}{$\Delta$ Protensão } & \multicolumn{3}{|c|}{$\sigma$ Solicitante $\left(\mathrm{MN} / \mathrm{m}^{2}\right)$} & \multirow{3}{*}{$\begin{array}{c}\Delta \sigma \text { Prot } \\
\left(\mathrm{MN} / \mathrm{m}^{2}\right)\end{array}$} & \multicolumn{4}{|c|}{$\sigma$ Total $\left(\mathrm{MN} / \mathrm{m}^{2}\right)$} & \multirow{3}{*}{ Verificar } \\
\hline & & \multirow{2}{*}{$\Delta$ Perm } & \multicolumn{2}{|c|}{ Acidental } & \multirow{2}{*}{$\mathrm{M}(\mathrm{kNm})$} & \multirow{2}{*}{$\mathrm{N}(\mathrm{kN})$} & \multirow{2}{*}{$\Delta$ Perm } & \multicolumn{2}{|c|}{ Acidental } & & \multirow{2}{*}{$\begin{array}{c}\text { Perm + } \\
\text { Prot }\end{array}$} & \multicolumn{3}{|c|}{ Perm + Prot + Acidental } & \\
\hline & & & + & - & & & & $\operatorname{Max}$ & Min & & & ELS-D & ELS-F & ELS-CE & \\
\hline \multirow{2}{*}{1} & & \multirow{2}{*}{0.8} & \multirow{2}{*}{28.1} & \multirow{2}{*}{-21.8} & \multirow{2}{*}{13.7} & -374 & 0.00 & 0.02 & -0.02 & 0.01 & -0.72 & -0.68 & -0.68 & -0.86 & - \\
\hline & Inf & & & & & -37.4 & 0.00 & 0.04 & -0.03 & 0.04 & -2.59 & -2.45 & -2.44 & -3.02 & - \\
\hline 2 & Sup & -55.5 & 0.0 & -2821 & -6.4 & -46.1 & 0.05 & 0.24 & 0.00 & 0.04 & -1.34 & -1.19 & -1.14 & -1.62 & - \\
\hline & $\operatorname{Inf}$ & -33.5 & 0.0 & $-\angle 82.1$ & -0.4 & -40.1 & -0.08 & 0.00 & -0.41 & 0.02 & -1.76 & -1.71 & -1.71 & -2.34 & - \\
\hline 3 & Sup & & & & & & 0.14 & 0.58 & 0.00 & 0.05 & -1.05 & -0.77 & -0.65 & -1.36 & - \\
\hline 3 & Inf & -169.9 & 0.0 & -685.0 & -13.8 & -55.8 & -0.24 & 0.00 & -0.98 & 0.02 & -2.46 & -2.42 & -2.42 & -3.55 & - \\
\hline 4 & \begin{tabular}{|l|} 
Sup \\
Inf
\end{tabular} & 29.7 & 256.1 & -457.1 & -10.7 & -59.7 & $\begin{array}{c}-0.03 \\
0.04\end{array}$ & $\begin{array}{l}0.39 \\
0.37\end{array}$ & $\begin{array}{l}-0.22 \\
-0.66\end{array}$ & $\begin{array}{l}0.05 \\
0.02\end{array}$ & $\begin{array}{l}-1.71 \\
-0.89\end{array}$ & $\begin{array}{l}-1.51 \\
-0.75\end{array}$ & $\begin{array}{l}-1.43 \\
-0.67\end{array}$ & $\begin{array}{l}-2.21 \\
-1.66\end{array}$ & - \\
\hline$=$ & Sup & 1560 & 5404 & $20<0$ & 18 & 527 & -0.13 & 0.25 & -0.46 & 0.02 & -1.31 & -1.20 & -1.15 & -1.90 & - \\
\hline 5 & Inf & 136.9 & 548.4 & 294.9 & 18.4 & 33.1 & 0.23 & 0.79 & -0.42 & 0.06 & -1.47 & -1.12 & -0.96 & -2.26 & - \\
\hline 6 & Sup & 2243 & 8007 & -1623 & 480 & -540 & -0.19 & 0.14 & -0.69 & -0.01 & -0.72 & -0.68 & -0.65 & -1.42 & - \\
\hline$b$ & Inf & 224.3 & 809.7 & -162.3 & 48.0 & -34.0 & 0.32 & 1.16 & -0.23 & 0.10 & -2.33 & -1.79 & -1.55 & -3.15 & - \\
\hline 7 & Sup & 230.8 & 9239 & -607 & 38.6 & -426 & -0.20 & 0.05 & -0.78 & 0.00 & -0.78 & -0.75 & -0.74 & -1.58 & - \\
\hline 1 & Inf & 230.8 & 923.9 & -60.7 & 38.6 & -42.6 & 0.33 & 1.33 & -0.09 & 0.08 & -2.05 & -1.46 & -1.19 & -2.72 & - \\
\hline 8 & Sup & 1753 & 9185 & 196 & 117 & -294 & -0.15 & 0.02 & -0.78 & 0.01 & -1.14 & -1.12 & -1.12 & -1.95 & - \\
\hline 8 & Inf & $1 / 3.3$ & 918.3 & -19.6 & 11.7 & -29.4 & 0.25 & 1.32 & -0.03 & 0.04 & -1.32 & -0.78 & -0.52 & -1.80 & - \\
\hline 9 & Sup & 118.1 & 750.8 & -180.1 & -0.8 & -164 & -0.10 & 0.15 & -0.64 & 0.01 & -0.73 & -0.68 & -0.64 & -1.41 & - \\
\hline & Inf & & & & -0.8 & -10.4 & 0.17 & 1.08 & -0.26 & 0.01 & -1.31 & -0.88 & -0.66 & -1.90 & - \\
\hline 10 & Sup & -5.3 & 4510 & -3781 & -150 & -110 & 0.00 & 0.32 & -0.38 & 0.02 & -0.59 & -0.45 & -0.39 & -1.09 & - \\
\hline 10 & Inf & -3.3 & 451.0 & $-3 / 8.1$ & -13.0 & -11.0 & -0.01 & 0.65 & -0.54 & -0.01 & -1.45 & -1.20 & -1.07 & -2.16 & - \\
\hline 11 & Sup & -1970 & 297 & -6125 & -291 & 46 & 0.17 & 0.52 & 0.03 & 0.03 & 0.43 & -0.20 & -0.09 & -0.71 & - \\
\hline 11 & \begin{tabular}{|l|}
$\ln$ \\
\end{tabular} & $-19 / .0$ & 29.1 & -612.5 & -29.1 & -4.6 & -0.28 & 0.04 & -0.88 & -0.04 & -1.62 & -1.58 & -1.58 & -2.51 & - \\
\hline 12 & Sup & -4570 & 00 & -883.5 & -382. & 4.3 & 0.39 & 0.75 & 0.00 & 0.03 & -0.75 & 0.11 & 0.26 & -0.66 & FLS-D \\
\hline 12 & Inf & $-45 / .0$ & 0.0 & -883.5 & -38.2 & 4.3 & -0.66 & 0.00 & -1.27 & -0.06 & -1.83 & -1.72 & -1.72 & -3.21 & - \\
\hline $13 \mathrm{E}$ & Sup & -741.5 & 0.0 & -1151.6 & -47.4 & -1.5 & 0.63 & 0.98 & 0.00 & 0.04 & 0.70 & 1.14 & 1.33 & 0.23 & ELS-D \\
\hline & Inf & & & & -47.4 & & -1.06 & 0.00 & -1.65 & -0.07 & -3.16 & -3.01 & -3.01 & -4.97 & - \\
\hline 130 & Sup & -734.9 & 00 & -1168.5 & -59.8 & -63.2 & 0.62 & 0.99 & 0.00 & 0.09 & -1.24 & -0.70 & -0.50 & -2.00 & - \\
\hline 130 & Inf & -734.9 & 0.0 & -1108.5 & -59.8 & -03.2 & -1.06 & 0.00 & -1.68 & -0.04 & -3.96 & -3.84 & -3.84 & -5.75 & - \\
\hline 14 & $\begin{array}{l}\text { Sup } \\
\text { Inf }\end{array}$ & -427.0 & 0.0 & -733.5 & -38.4 & -74.8 & $\begin{array}{c}0.36 \\
-0.61\end{array}$ & $\begin{array}{l}0.62 \\
0.00\end{array}$ & $\begin{array}{c}0.00 \\
-1.05\end{array}$ & $\begin{array}{c}0.08 \\
-0.01\end{array}$ & $\begin{array}{l}-1.60 \\
-3.18\end{array}$ & $\begin{array}{l}-1.22 \\
-3.15\end{array}$ & $\begin{array}{l}-1.10 \\
-3.15\end{array}$ & $\begin{array}{l}-2.19 \\
-4.26\end{array}$ & - \\
\hline & Sup & 1907 & & & & & 0.14 & 0.40 & -0.02 & 0.06 & -1.96 & -1.70 & -1.62 & -2.42 & - \\
\hline 15 & Inf & -164.7 & 26.8 & -469.9 & -12.8 & -82.5 & -0.24 & 0.04 & -0.67 & 0.04 & -2.58 & -2.51 & -2.50 & -3.43 & - \\
\hline 16 & Sup & 467 & 4413 & -2316 & 9.5 & -358 & -0.04 & 0.20 & -0.37 & 0.05 & -2.34 & -2.18 & -2.14 & -3.03 & - \\
\hline 16 & \begin{tabular}{|l|}
$\ln$ \\
\end{tabular} & 4b. 7 & 441.3 & & 9.5 & -85.8 & 0.07 & 0.63 & -0.33 & 0.07 & -1.98 & -1.67 & -1.54 & -2.69 & - \\
\hline 17 & Sup & 206.3 & 774.7 & -19.1 & 25.1 & -85.8 & -0.17 & 0.02 & -0.66 & 0.03 & -2.72 & -2.63 & -2.63 & -3.61 & - \\
\hline & Inf & 200.3 & 174.7 & -19.1 & & & 0.30 & 1.11 & -0.03 & 0.09 & -1.39 & -0.89 & -0.66 & -1.94 & - \\
\hline 18 & Sup & 333 & 10395 & O & 311 & -826 & -0.27 & 0.00 & -0.88 & 0.03 & -3.12 & -3.05 & -3.05 & -4.19 & - \\
\hline 18 & Inf & 313.3 & 1039.5 & 0.0 & 31.1 & -82.6 & 0.45 & 1.49 & 0.00 & 0.10 & -0.77 & -0.12 & 0.18 & -1.38 & - \\
\hline 19 & Sup & 4487 & 1189.3 & 00 & 538 & -83.8 & -0.38 & 0.00 & -1.01 & 0.01 & -3.03 & -2.99 & -2.99 & -4.13 & - \\
\hline 19 & \begin{tabular}{|l|}
$\operatorname{lnf}$ \\
\end{tabular} & 448.7 & 1189.3 & & 33.8 & -83.8 & 0.64 & 1.71 & 0.00 & 0.13 & -0.82 & -0.06 & 0.28 & -1.58 & - \\
\hline 20 & Sup & 490.9 & 1162.2 & 0.0 & 51.1 & -75.9 & -0.42 & 0.00 & -0.98 & 0.01 & -3.03 & -3.01 & -3.01 & -4.08 & - \\
\hline 20 & Inf & & & & & & 0.70 & 1.67 & 0.00 & 0.12 & 0.69 & 0.06 & 0.40 & -1.47 & ELSDD \\
\hline
\end{tabular}

B Second phase (Pavement and concrete barrier loads, $t=28$ days) 
Figure 17c - Results of Guarita Viaduct - North

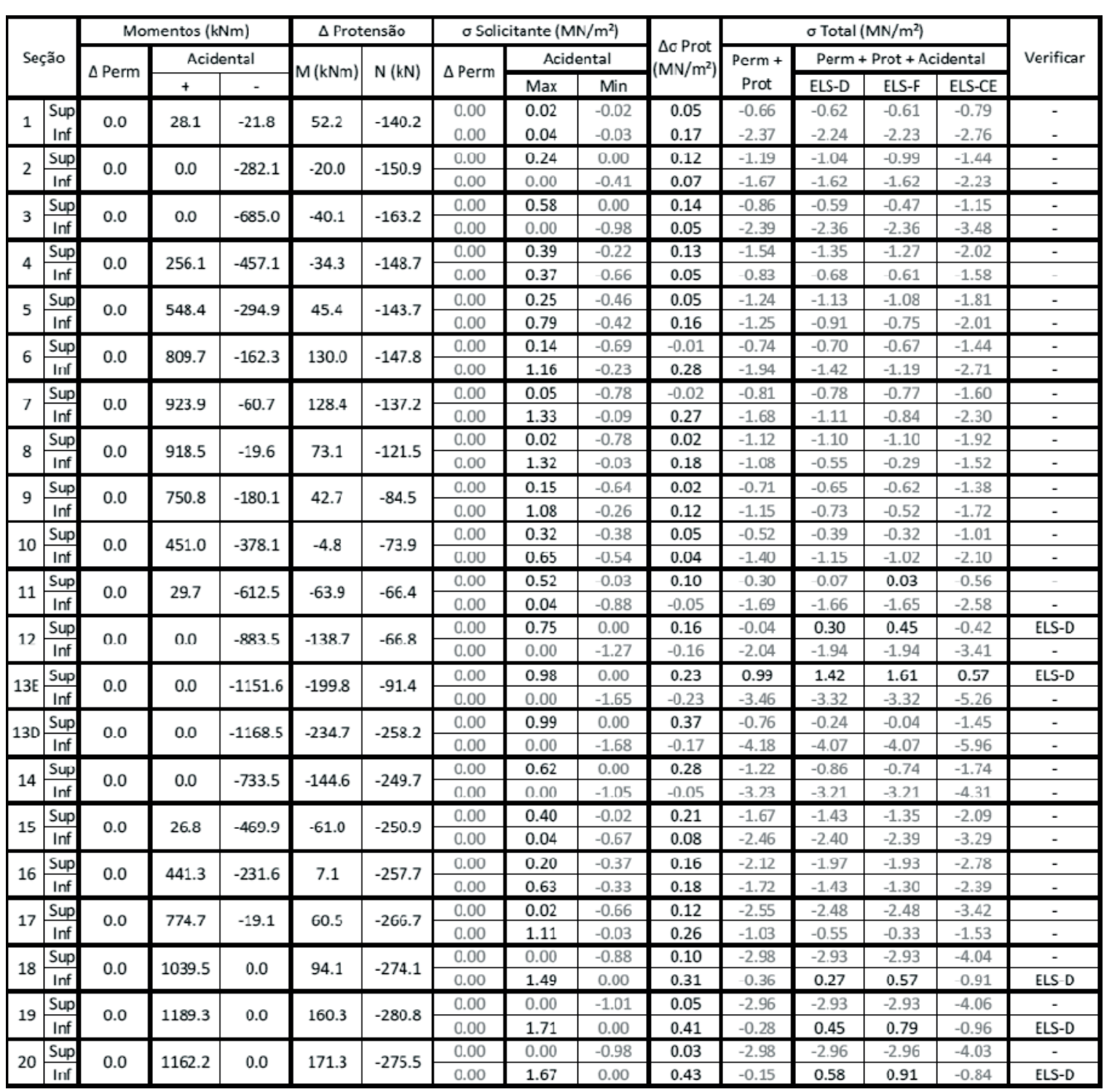

C Last phase (end of service life, $t=18250$ days) 